\title{
Experimental and numerical investigation into strengthening flat slabs at corner columns with externally bonded CFRP
}

DOI:

10.1016/j.conbuildmat.2017.02.056

\section{Document Version}

Accepted author manuscript

Link to publication record in Manchester Research Explorer

Citation for published version (APA):

Abdulrahman, B., Wu, Z-J., \& Cunningham, L. (2017). Experimental and numerical investigation into strengthening flat slabs at corner columns with externally bonded CFRP. Construction and Building Materials, 139, 132-147. https://doi.org/10.1016/j.conbuildmat.2017.02.056

\section{Published in:}

Construction and Building Materials

\section{Citing this paper}

Please note that where the full-text provided on Manchester Research Explorer is the Author Accepted Manuscript or Proof version this may differ from the final Published version. If citing, it is advised that you check and use the publisher's definitive version.

\section{General rights}

Copyright and moral rights for the publications made accessible in the Research Explorer are retained by the authors and/or other copyright owners and it is a condition of accessing publications that users recognise and abide by the legal requirements associated with these rights.

\section{Takedown policy}

If you believe that this document breaches copyright please refer to the University of Manchester's Takedown Procedures [http://man.ac.uk/04Y6Bo] or contact uml.scholarlycommunications@manchester.ac.uk providing relevant details, so we can investigate your claim.

\section{OPEN ACCESS}




\title{
Experimental and numerical investigation into strengthening flat slabs at corner columns with externally bonded CFRP
}

\author{
* Bassam Q. Abdulrahman ${ }^{1,2}$, Zhangjian $\mathrm{Wu}^{1}$, Lee S. Cunningham ${ }^{1}$ \\ ${ }^{1}$ University of Manchester, School of Mechanical, Aerospace \& Civil Engineering \\ Manchester M13 9PL, United Kingdom \\ ${ }^{2}$ Darbandikhan Technical Institute, Al-Sulaymania, Iraq \\ * Bassam.abdulrahman@ postgrad.manchester.ac.uk
}

\begin{abstract}
This research investigates the effectiveness of strengthening flat slab to column corner connections by using carbon fibre reinforced polymer (CFRP) sheets. Towards this, four full scale un-strengthened and strengthened flat slab specimens were studied experimentally. Further variation in the test series was introduced via addition of openings near the slab column intersections. The structural performance of the strengthened specimens was compared with that of the un-strengthened specimen in terms of ultimate punching shear resistance, deflection profile and strain profile etc. From the series of slabs tested, it can be concluded that strengthening in the slab without the opening increased the ultimate punching shear capacity by $11 \%$, while in the case of the slab with openings, strengthening increased the punching shear capacity by up to $23 \%$. In parallel with the experimental work, a numerical study was also conducted in order to gain further insight into the structural behaviour of the slabs.
\end{abstract}

Key-words: Concrete slabs, Corner columns, Punching shear, CFRP, Strengthening

\section{Introduction}

The ease of construction and minimum depth presented by flat slabs has made them widely used in the construction of buildings for many decades [1]. Despite their inherent advantages, flat slabs are by their nature vulnerable to punching shear failure.

As a means of strengthening existing flat slabs, fibre reinforced polymers have been used to enhance the structural performance of slab to column zones by providing post-cracking tensile resistance and controlling the width of the cracks [2]. To date, a significant number of investigations have been conducted on strengthening existing slab to column connections for internal columns [3]. All investigations have examined methods to delay or prevent punching shear failure. One popular strengthening method is the direct strengthening of slabs against 
punching shear by using vertical FRP bars or rods as shear studs or as loops from top to bottom surfaces through the slab thickness. Several researchers have studied this method [46]. In all the previous work, researchers aimed at understanding the capability of CFRP in reinforcing concrete slabs against punching shear under different variables in particular the concrete strength, flexural capacity of the un-strengthened section and the arrangement of the CFRP reinforcement around the columns. The reported punching shear capacity enhancement varies widely depending on the amount of FRP used and the geometry of the specimen, it has been reported that this method can increase the slab strength by $17 \%$ to $133 \%$ [7, 8] (see Table 1). The disadvantage of this method is that it requires drilling through the thickness of the slab to allow post-fixing of the FRP, and is hence an intrusive procedure with associated risks such as rebar strikes etc. One alternative method to strengthen the slab to column zone may be described as the indirect method [2]. This method relies on strengthening the slabs in flexure by adding prestressed or nonprestressed FRP sheets or plates to the exposed surface of the slab, thus the shear strength may increase indirectly to varying degrees. As described by Muttoni [9] the punching shear strength of a slab decreases by the formation of a shear crack propagating through the slab thickness. At the flat slab to column zone, a compressive stress field which may be idealised as an inclined strut is generated through the depth of the slab and carries the shear forces to the column. In the lead up to punching shear failure, tensile stresses are generated transverse to the inclined strut leading to cracking. The shear strength of the section decreases progressively as the shear crack opens eventually leading to punching shear failure. This forms the basis for application of surface mounted FRP reinforcement, enhancing the ability of the system to carry the tensile stresses, reducing the opening of cracks at comparative load levels thus delaying the onset of punching shear.

Given the relative ease of application and non-intrusive nature, the indirect method has been investigated by a number of researchers [10-12]. Across these studies, it has been found that by using this method the punching shear resistance can be increased between $2 \%$ to $114 \%$ depending on the amount of FRP, FRP offset position and configuration. Table 1 gives a summary of relevant work in these two strengthening methods.

The vast majority of the readily available previous studies focus on interior slab column connections where moment transfer is usually relatively small or negligible [13]. In most of the quoted experimental studies mentioned in Table 1, a single column stub was positioned in the middle of the slab and the boundaries represented the line of contraflexure. 
Although it is convenient to test flat slab-column junctions under this boundary condition, the in-service boundaries are often not properly represented.

For the specific case of un-strengthened corner slab column connections, limited data is currently available. In these types of slabs there is often a significant interaction between the eccentric axial load (as a result of the slab geometry) and transferred moment. The existing studies on corner slabs can be classified into three categories: (1) isolated models consisting of one corner column and a part of a slab representing the negative moment area; (2) a whole slab supported by four corner columns which provide a realistic representation of the corner region of a flat slab and (3) multi-panel slabs [14].

The present study seeks to address the current lack of readily available data on CFRP strengthened corner flat slabs. Furthermore, since the introduction of openings into an existing slab is a common cause for the need for strengthening, the efficacy of using CFRP in this scenario will also be explored. Openings are often needed to accommodate additional services, ducts, lifts and stairwells etc. To date there are no readily available experimental studies on the effect of CFRP strengthening where openings exist near the corner column, and especially adjacent to the slab free edge.

The structure of this paper is as follows. First the experimental set-up is described in section 2. This is followed by a brief description of the numerical model employed in section 3 . The results of the experimental and numerical models are then presented together for discussion in section 4 , followed by a numerical parametric study on strengthening layouts in section 5 . 
Table 1 Summary of existing experimental work

\begin{tabular}{|c|c|c|c|c|c|c|c|}
\hline $\begin{array}{l}\text { Strengthening } \\
\text { method }\end{array}$ & Researcher & Type of sample test & $\begin{array}{l}\text { Specimen dimensions } \\
(\mathrm{mm})\end{array}$ & $\begin{array}{c}\text { Number of } \\
\text { samples }\end{array}$ & Strengthening with FRP & $\begin{array}{l}\% \text { enhancement in } \\
\text { ultimate strength }\end{array}$ & Failure mode \\
\hline \multirow{5}{*}{$\begin{array}{c}\text { Direct } \\
\text { strengthening }\end{array}$} & $\begin{array}{l}\text { Sissakis and Sheikh } \\
2007[5]\end{array}$ & $\begin{array}{l}\text { Interior slab column } \\
\text { connections }\end{array}$ & $1500 \times 1500 \times 150$ & 32 & $\begin{array}{l}\text { CFRP laminates as shear } \\
\text { reinforcement }\end{array}$ & 80 & punching shear failure \\
\hline & $\begin{array}{c}\text { Binici and Bayrak } \\
2003,2005[6,15,16]\end{array}$ & $\begin{array}{l}\text { Interior slab column } \\
\text { connections }\end{array}$ & $2133 \times 2133 \times 152$ & 15 & $\begin{array}{l}\text { CFRP strips vertically around the } \\
\text { column }\end{array}$ & 60 & $\begin{array}{l}\text { punching (control) to flexural } \\
\text { punching (strengthened) }\end{array}$ \\
\hline & Erdogan $2010[8]$ & $\begin{array}{l}\text { Interior slab column } \\
\text { connections }\end{array}$ & $2130 \times 2130 \times 150$ & 5 & $\begin{array}{l}\text { strips driven vertically through the } \\
\text { slab thickness, some fanned }\end{array}$ & $33.4-133$ & punching shear \\
\hline & $\begin{array}{c}\text { Meisami et al. } \\
2013[16]\end{array}$ & $\begin{array}{l}\text { Interior slab column } \\
\text { connections }\end{array}$ & $1200 \times 1200 \times(85,105)$ & 6 & FRP rods through the slab thickness & $\begin{array}{l}17 \text { for } 8 \text { rods } \\
67 \text { for } 24 \text { rods }\end{array}$ & $\begin{array}{l}\text { punching (control) to flexure } \\
\text { (strengthened) }\end{array}$ \\
\hline & $\begin{array}{c}\text { Meisami et al. } \\
\text { 2015[17] }\end{array}$ & $\begin{array}{c}\text { Interior slab column } \\
\text { connections }\end{array}$ & $1200 \times 1200 \times(85,105)$ & 6 & fanned FRP through the thickness & $29.7-72.5$ & $\begin{array}{c}\text { punching (control) to flexural } \\
\text { punching or flexural (strengthened) }\end{array}$ \\
\hline \multirow{8}{*}{$\begin{array}{c}\text { Indirect } \\
\text { strengthening }\end{array}$} & $\begin{array}{c}\text { Erki and Heffernan } \\
1995[10]\end{array}$ & $\begin{array}{l}\text { Interior slab column } \\
\text { connections }\end{array}$ & $1000 \times 1000 \times 50$ & 6 & externally bonded GRP and FRP & $\begin{array}{l}19 \text { for GRP } \\
84 \text { for CFRP }\end{array}$ & $\begin{array}{l}\text { flexure (control) to punching } \\
\text { (strengthened) }\end{array}$ \\
\hline & $\begin{array}{c}\text { Ebead and Marzouk } \\
2004[2]\end{array}$ & $\begin{array}{c}\text { Interior slab column } \\
\text { connections }\end{array}$ & $1900 \times 1900 \times 150$ & 3 & $\begin{array}{l}\text { CFRP, GRP strips of L shape in } \\
\text { addition to steel bolts }\end{array}$ & 9 & punching shear \\
\hline & $\begin{array}{c}\text { El-Salakawy et al } \\
2004[11]\end{array}$ & $\begin{array}{l}\text { Edge slab column } \\
\text { connections }\end{array}$ & $1540 \times 1020 \times 120$ & 7 & $\begin{array}{c}\text { externally bonded GRP or CFRP } \\
\text { sheets }\end{array}$ & $\begin{array}{l}2-6 \text { for one FRP layer } \\
22 \text { for two FRP layers }\end{array}$ & punching shear \\
\hline & $\begin{array}{c}\text { Sharaf et al. } 2006 \\
\text { [12] }\end{array}$ & $\begin{array}{l}\text { Interior slab column } \\
\text { connections }\end{array}$ & $2000 \times 2000 \times 150$ & 5 & various $\mathrm{CFRP}$ configurations & $6-16$ & punching shear \\
\hline & $\begin{array}{c}\text { Urban and Tarka } \\
2010[18]\end{array}$ & $\begin{array}{c}\text { Interior slab column } \\
\text { connections }\end{array}$ & $2300 \times 2300 \times 180$ & 4 & $\begin{array}{l}\text { CFRP strips with additional shear } \\
\text { bolts }\end{array}$ & $\begin{array}{l}10 \text { for CFRP } \\
36 \text { for additional bolts }\end{array}$ & punching shear \\
\hline & $\begin{array}{c}\text { Abdullah et al. } 2013 \\
\text { [19] }\end{array}$ & $\begin{array}{l}\text { Interior slab column } \\
\text { connections }\end{array}$ & $1800 \times 1800 \times 150$ & 5 & $\begin{array}{c}\text { nonprestressed and prestressed CFRP } \\
\text { plates }\end{array}$ & $\begin{array}{c}42 \text { for nonprestressed } \\
8 \text { for prestressed }\end{array}$ & $\begin{array}{l}\text { flexure (control) to punching } \\
\text { (strengthened) }\end{array}$ \\
\hline & $\begin{array}{c}\text { Koppitz et al. } \\
\text { 2014[20] }\end{array}$ & $\begin{array}{l}\text { Interior slab column } \\
\text { connections }\end{array}$ & $\begin{array}{c}3200 \times 3200 \times(260,180, \\
320)\end{array}$ & 3 & prestressed CFRP plates & $67-114$ & punching shear \\
\hline & $\begin{array}{l}\text { Durucan and Anil } \\
2015[3]\end{array}$ & $\begin{array}{l}\text { Interior slab column } \\
\text { connections }\end{array}$ & $2000 \times 2000 \times 120$ & 8 & 4-orthogonal CFRP sheets & 55 & punching shear \\
\hline
\end{tabular}




\section{Experimental Programme}

\subsection{Test specimen}

The experimental programme comprised testing of four discrete flat slabs which were designed and fabricated in order to investigate corner slab-column behaviour. All the slabs were $2 \mathrm{~m} \times 2 \mathrm{~m}$ square with a thickness of $80 \mathrm{~mm}$. These slabs were attached to four 160 $\mathrm{mm} \times 160 \mathrm{~mm}$ square, $720 \mathrm{~mm}$ high columns cast monolithically with the slab as shown in Fig. 1(c). Slab 1 was the control specimen in which the slab was unaltered, i.e. without openings and without CFRP strengthening. This was designed to fail in punching shear at a total load of $36 \mathrm{kN} / \mathrm{m}^{2}$ (including self-weight) based on Eurocode 2 [21]. Slab 2 was similar to the control specimen but strengthened with CFRP sheets of a width of $50 \mathrm{~mm}$ and a thickness of $0.6 \mathrm{~mm}$ around the corner columns as shown in Fig. 1(a). The remaining two slabs 3 and 4 had openings near the slab-column intersection as shown in Fig. 1(b). For the slabs with openings, the investigated opening size is set not to exceed $80 \%$ of the square column size in line with general recommendations [22]. Consequently an opening size of 100 $\mathrm{mm} \times 100 \mathrm{~mm}$ was formed close to each column. The reinforcing details of all the slabs are presented in Table 2. All the strengthened slabs used the same previously described CFRP sheets bonded externally to the top surface of the slab (i.e. the loaded surface), around the four columns in an orthogonal configuration.

The CFRP sheets were extended along the slab surface by between 340 and $500 \mathrm{~mm}$ for all strengthened slabs as detailed in Fig. 1. This length was greater than the effective length of $153 \mathrm{~mm}$ calculated following the suggestion of ACI committee-440-2R [23] and greater than the effective bond length investigated as part of a parametric study using the FE model described in section 3. The numerical study varied the bond length from $350 \mathrm{~mm}$ to $500 \mathrm{~mm}$ on the concrete top surface. In all cases an additional length of CFRP extended $80 \mathrm{~mm}$ down the sides of the concrete at the slab edges. The $80 \mathrm{~mm}$ (i.e. slab thickness) extension around the sides was also the result of the same numerical study where lengths of $40 \mathrm{~mm}, 80 \mathrm{~mm}$ and $160 \mathrm{~mm}$ were explored. The $40 \mathrm{~mm}$ case was found to be the threshold, at lengths greater than this early de-bonding did not occur. Based on the numerical study, a CFRP length of $500 \mathrm{~mm}$ in addition to the $80 \mathrm{~mm}$ around the edges was used in the experimental study. In general the CFRP sheets were attached adjacent to the slab column connection at a distance of $15 \mathrm{~mm}$ away from the column face due to practical constraints. 


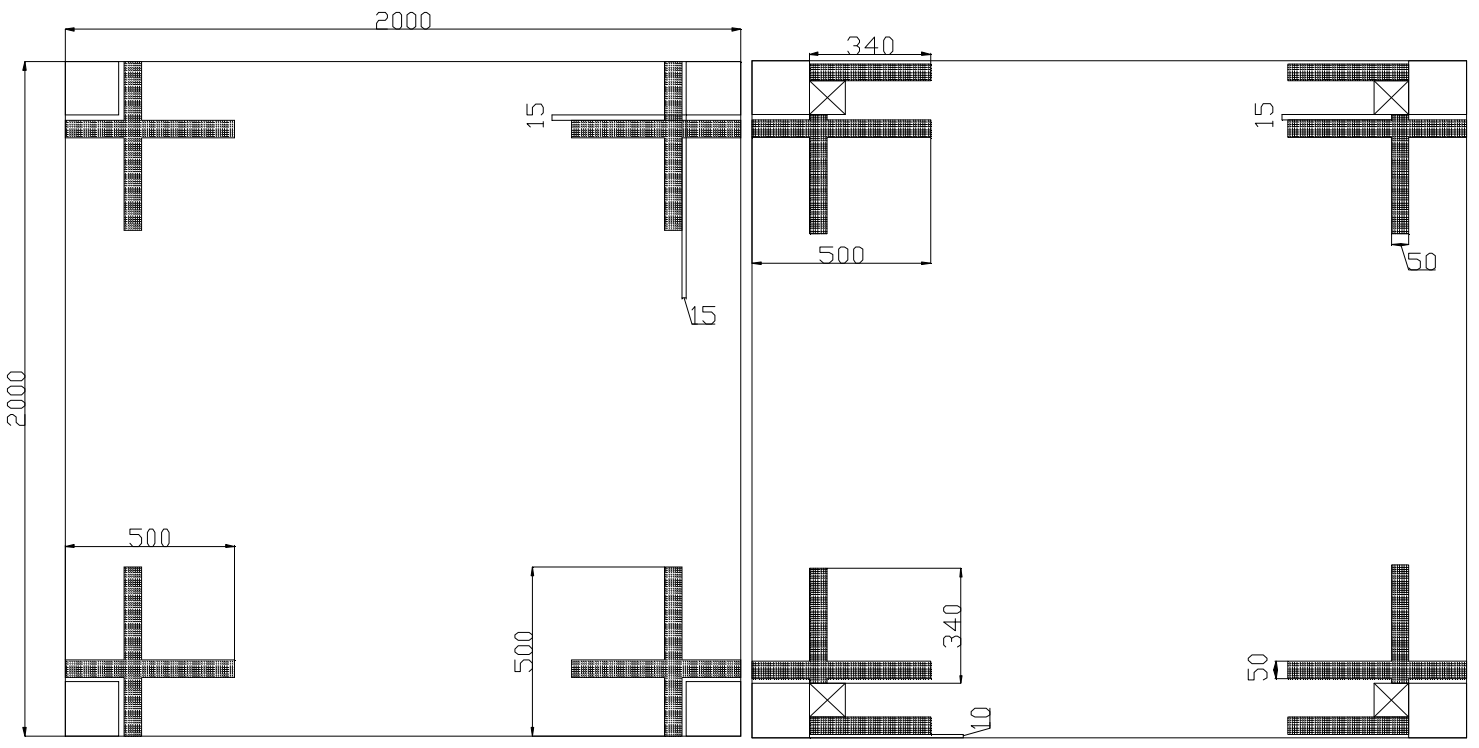

(a) Slab 2 plan view

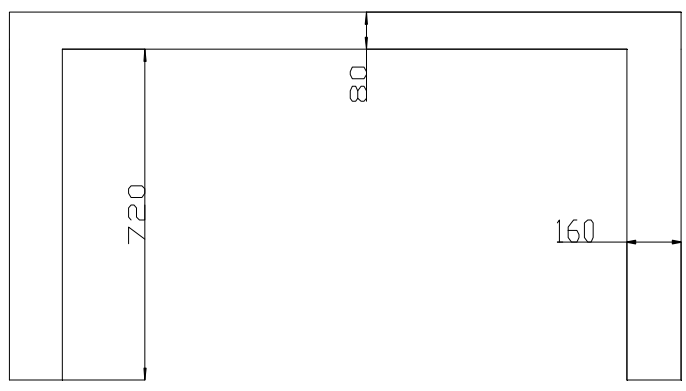

(b) Slabs 3 and 4 plan view

All the dimensions are in $\mathrm{mm}$.

The CFRP sheets are extended beyond the slabs edges by $80 \mathrm{~mm}$.

(c) Slabs 1-4 end elevation

Fig. 1 Specimen geometry and strengthening configuration

Table 2 Details of the slab test series

\begin{tabular}{|c|c|c|c|c|c|}
\hline Specimen & $\begin{array}{l}\text { Bottom steel } \\
\text { reinforcement }\end{array}$ & Top steel reinforcement & $\begin{array}{c}\text { Column reinforcement and } \\
\text { stirrups }\end{array}$ & CFRP strengthening & $\begin{array}{l}\text { Existence } \\
\text { of opening }\end{array}$ \\
\hline slab 1 & $\begin{array}{c}6 \text { mm @ } 90 \\
\text { mm with } \\
\text { concrete clear } \\
\text { cover of } 10- \\
\text { mm }\end{array}$ & $\begin{array}{c}4 \text { of } 6 \mathrm{~mm} @ 200 \mathrm{~mm} \\
\text { over each column } \\
\text { extending } 650 \mathrm{~mm} \text { in each } \\
\text { direction with concrete } \\
\text { cover of } 10-\mathrm{mm}\end{array}$ & $\begin{array}{l}\text { Longitudinal } \\
\text { reinforcement: } 4 \text { of } 12- \\
\mathrm{mm} \\
\text { Stirrups: } 6 \mathrm{~mm} \text { distributed } \\
\text { every } 150-\mathrm{mm}\end{array}$ & No strengthening & No opening \\
\hline
\end{tabular}

\subsection{Material properties}

The flat slab specimens were cast on the same day from the same batch of concrete with a target 28 -day cylinder compressive strength of $40 \mathrm{MPa}$. Six concrete cylinders of $(150 \times 300)$ $\mathrm{mm}$ were tested at 28 days in order to find the average concrete mechanical properties as 
shown in Table 3 . Further to this, twelve $(150 \times 150 \times 150) \mathrm{mm}$ cubes (in place of cylinders due to practical constraints) were used to determine the compression strength on the day of testing.

Table 3 Concrete properties

\begin{tabular}{|c|c|c|c|c|c|}
\hline \multirow[b]{2}{*}{ Slab } & \multicolumn{3}{|c|}{ Properties at 28 days } & \multirow[b]{2}{*}{$\begin{array}{l}\text { Age at } \\
\text { test: days }\end{array}$} & \multirow{2}{*}{$\begin{array}{c}\text { Cube } \\
\text { compressive } \\
\text { strength at test } \\
\text { day: } \\
(\mathrm{MPa})\end{array}$} \\
\hline & $\begin{array}{c}\text { Cylinder } \\
\text { compressive } \\
\text { strength } \\
(\mathrm{MPa})\end{array}$ & $\begin{array}{l}\text { Tensile } \\
\text { strength } \\
(\mathrm{MPa})\end{array}$ & $\begin{array}{l}\text { Modulus of } \\
\text { elasticity } \\
(\mathrm{GPa})\end{array}$ & & \\
\hline Slabs 1\&2 & 37.8 & 2.9 & 28.3 & 70 & 49.2 \\
\hline Slabs $3 \& 4$ & 37.8 & 2.9 & 28.3 & 71 & 49.3 \\
\hline
\end{tabular}

The tensile properties of the steel reinforcement were also investigated by testing samples to find the yield strength, ultimate strength and the elongation. Table 4 shows the mechanical properties of the steel rebar.

Table 4 Mechanical properties of the steel rebars

\begin{tabular}{|c|c|c|c|c|}
\hline $\begin{array}{c}\text { Diameter } \\
(\mathrm{mm})\end{array}$ & $\begin{array}{c}\text { Young Modulus } \\
(\mathrm{GPa})\end{array}$ & $\begin{array}{c}\text { Yield stress } \\
(\mathrm{MPa})\end{array}$ & Yield strain & $\begin{array}{c}\text { Ultimate stress } \\
(\mathrm{MPa})\end{array}$ \\
\hline 6 & 198 & 597 & 0.003 & 629 \\
\hline 12 & 167 & 570 & 0.0034 & 655 \\
\hline
\end{tabular}

One type of unidirectional CFRP sheet was used in this study. The material was provided by Easycomposites, UK [24]. CFRP sheets were used together with Weber.tec EP structural adhesive to form the composite strengthening system in accordance with Concrete Society Technical Report 55 [25]. Table 5 gives the material properties of the CFRP sheets and the bonding adhesive used in this study.

Table 5 Properties of CFRP composite materials

\begin{tabular}{|c|c|c|c|c|}
\hline Material & $\begin{array}{c}\text { Thickness } \\
(\mathrm{mm})\end{array}$ & $\begin{array}{c}\text { Modulus of } \\
\text { Elasticity } \\
(\mathrm{GPa})\end{array}$ & $\begin{array}{c}\text { Shear Modulus } \\
(\mathrm{GPa})\end{array}$ & $\begin{array}{c}\text { Tensile Strength } \\
(\mathrm{MPa})\end{array}$ \\
\hline Epoxy Resin & - & 5 & 1.8 & 19 \\
\hline Composite sheet & 0.8 & $96.3^{\mathrm{a}}, 6.7^{\mathrm{b}}$ & $2.8_{(\mathrm{xy})}, 2.5_{(\mathrm{yz})}$ & $911^{\mathrm{a}}, 40^{\mathrm{c}}$ \\
\hline $\begin{array}{l}{ }^{\mathrm{a}} \text { parallel to fibre direction } \\
\mathrm{b} \text { perpendicular to fibre direction } \\
{ }^{\mathrm{c}} \text { perpendicular to fibre direction based on the manufacturer's specification }\end{array}$ \\
\hline
\end{tabular}




\subsection{Surface preparation and bonding process for the strengthened samples}

To develop a full bond adhesion between the CFRP and the concrete surface, the surface was prepared by cleaning and levelling the concrete substrate. The bonding adhesive was applied to both the CFRP and the concrete surface taking care to avoid air bubbles. The adhesive layer was formed by mixing 2/3 Epoxy resin and 1/3 Epoxy hardener as provided by Weber Building Solutions, UK [26]. The CFRP was attached to the concrete surface by hand, achieving adhesion and without causing a loss in the required adhesive thickness of $3 \mathrm{~mm}$ in accordance with Concrete Society Technical Report 55 [25].

\subsection{Test procedure and instrumentation}

Each slab to column zone was instrumented to provide detailed information regarding the structural behaviour throughout the entire loading history. The data recorded in the test comprised loading, deflections, strains in the steel and CFRP sheets. Loading was applied gradually at a rate of $3 \mathrm{kN} / \mathrm{min}$ from a hydraulic jack with a capacity of $2500 \mathrm{kN}$. To apply a uniformly distributed load on the slab, a steel frame consisting of one plate with dimensions $1500 \mathrm{~mm} \times 1500 \mathrm{~mm} \times 20 \mathrm{~mm}$ stiffened by a series of $50 \mathrm{~mm} \times 50 \mathrm{~mm} \times 2 \mathrm{~mm}$ square hollow sections was used (Fig. 2). Below the hollow sections, 16 arrayed steel pads each with dimensions $50 \mathrm{~mm} \times 50 \mathrm{~mm} \times 10 \mathrm{~mm}$ at $500 \mathrm{~mm}$ centres were used to deliver the patch loads to the slab surface, thus approximating a uniformly distributed load as shown in Fig. 3. All the four columns of each slab were designed to be pin-supported at the base. The deflection profile of the slab was measured via a LVDT at the centre of the lower face of the slab.

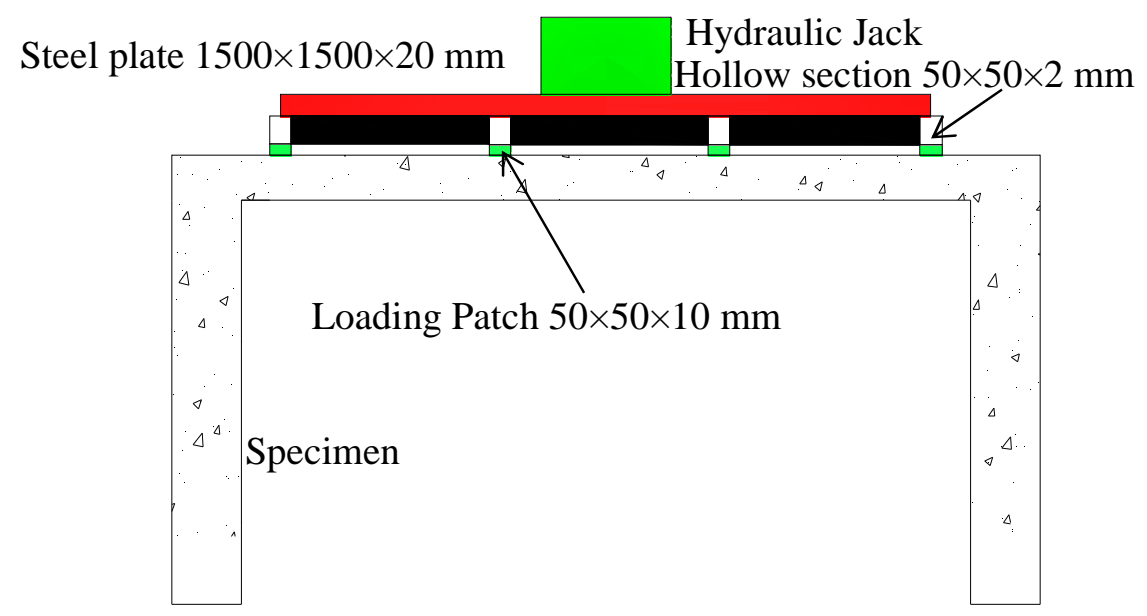

(a) Schematic view 


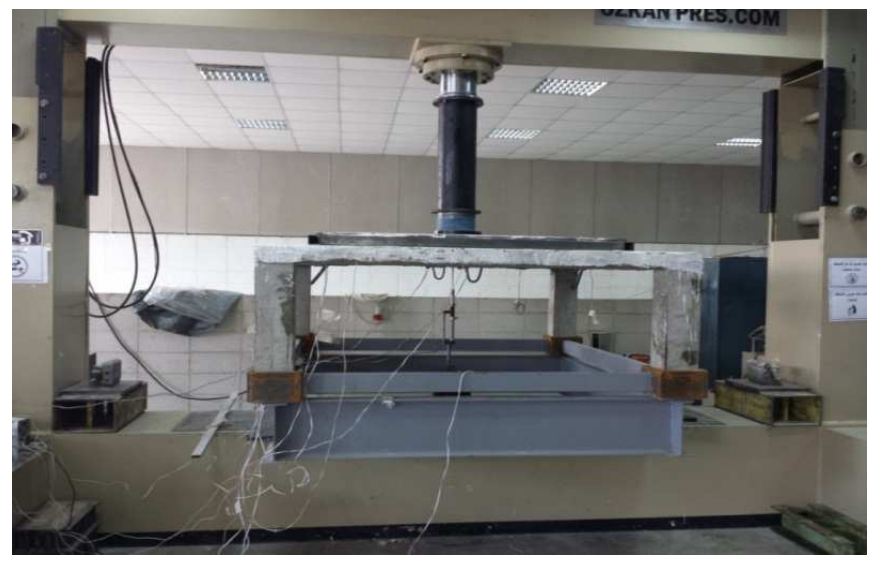

(b) Laboratory photograph

Fig. 2 Test setup for the RC slab

To measure the strains in the steel, six strain gauges were fixed to the rebar as shown in Fig. 4. In the strengthened slabs, three more strain gauges were attached to the CFRP sheets to measure the average longitudinal strain as shown in Fig. 5.

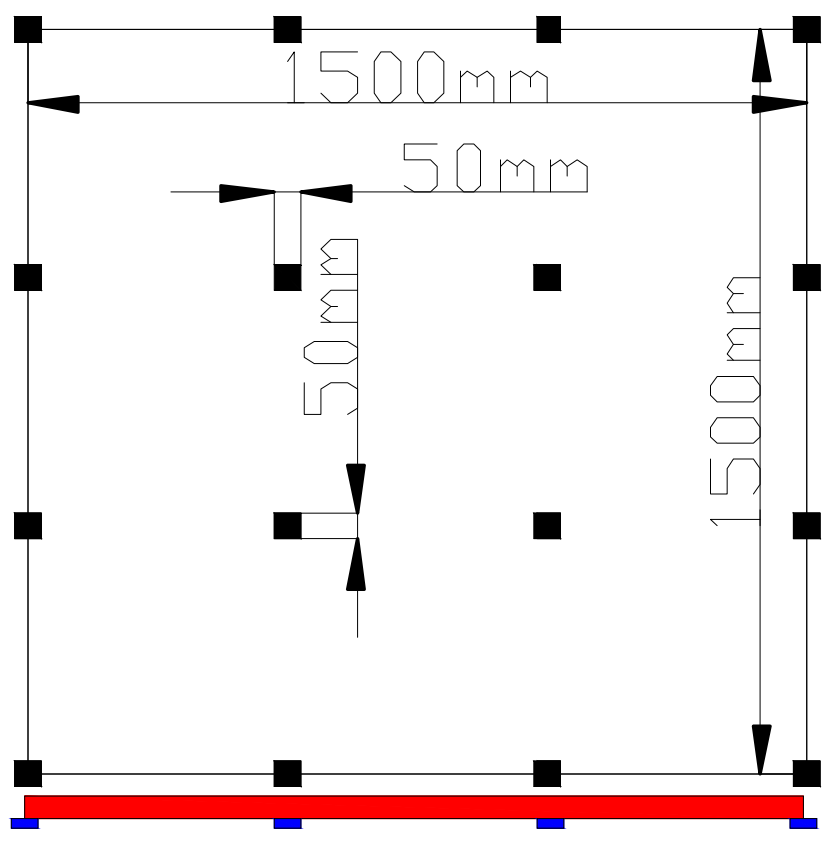

Fig. 3 Array of loading patches 


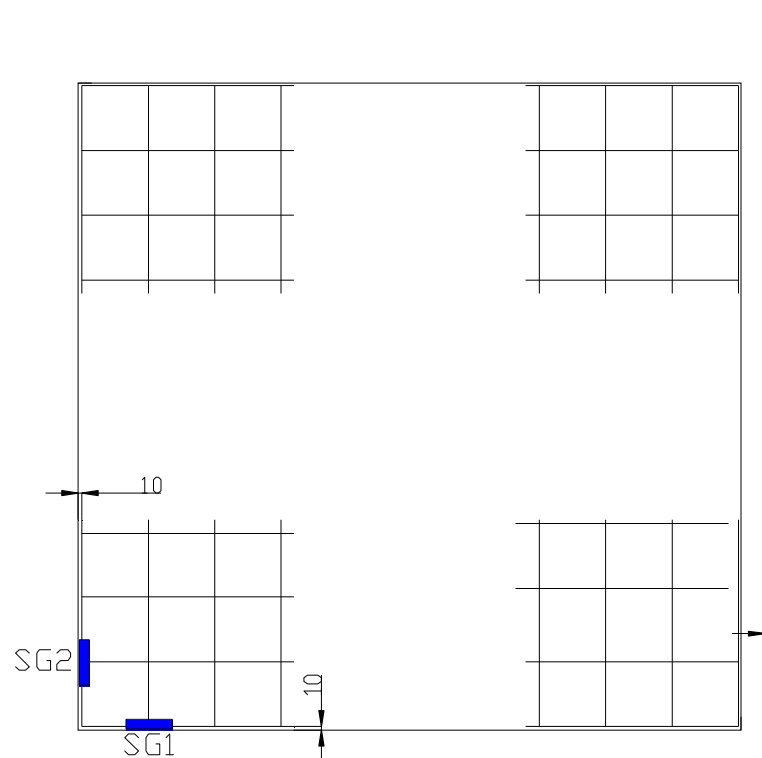

(a) Top steel reinforcement

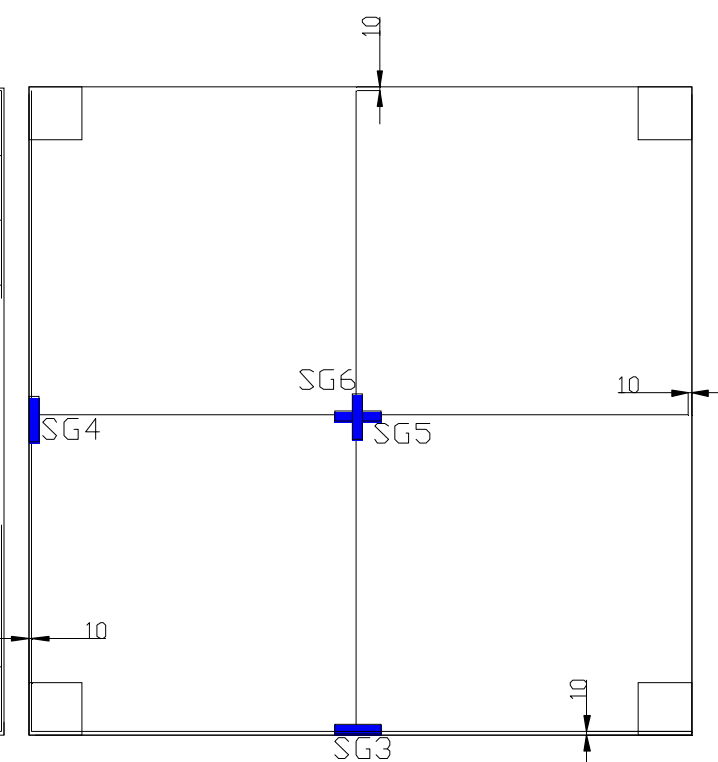

(b) Bottom steel reinforcement (full rebar layout omitted for clarity)

Fig. 4 Arrangement of steel strain gauges

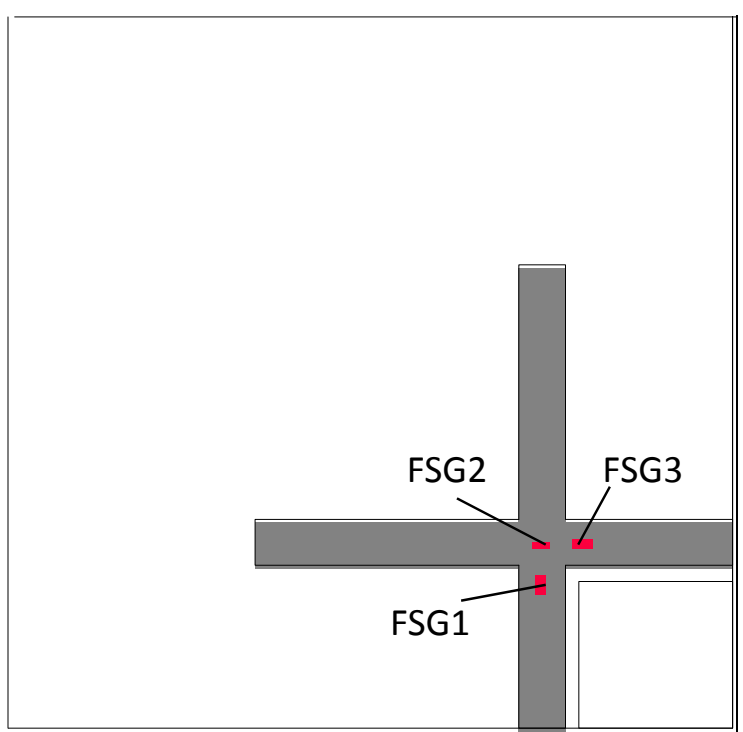

(a) Slab 2

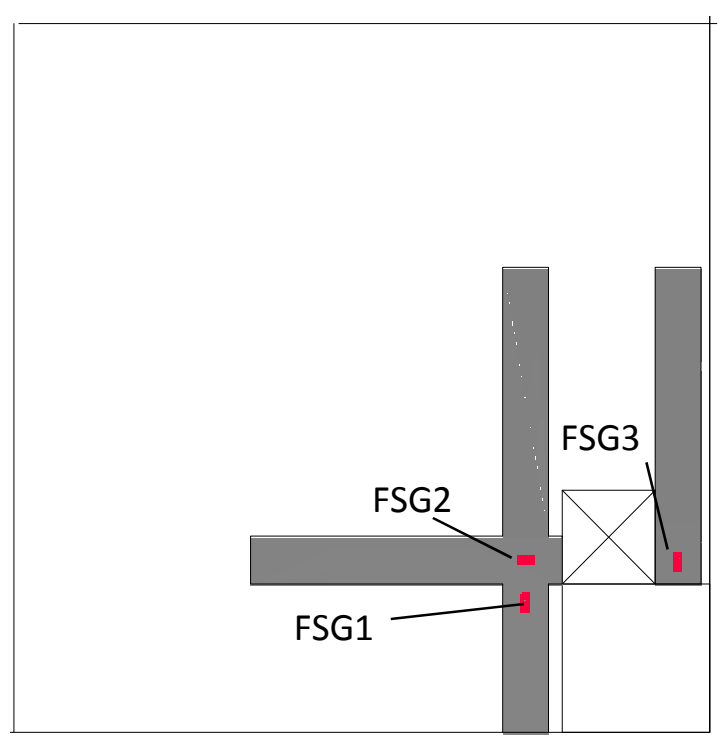

(b) Slabs 3 and 4 (plan view on quarter slab)

Fig. 5 CFRP strain gauges

\section{Finite Element Modelling of Tested Specimens}

The finite element software ABAQUS [27] was used in this study to simulate the structural behaviour of the test slabs. Because of the symmetry in loading and boundary conditions, a quarter of each slab specimen was modelled. To model the concrete, 8 node 3D continuum elements (C3D8R) with an element size of $20 \mathrm{~mm}$ and six elements through the slab 
thickness were chosen based on mesh sensitivity analysis for the concrete. The concrete material behaviour was modelled by the damage plasticity model which is able to represent the compressive crushing and the tensile cracking of brittle materials [27]. For the compression behaviour, the stress-strain relationship described by Eurocode 2 [21] was adopted. The tensile behaviour was based on the exponential relationship between the tensile stresses and the concrete crack width described by the equation of Cornelissen et al. [28]. The reinforcement mesh consists of 2-node truss elements (T3D2) was modelled as an elastic plastic material based on the properties in Table 4. The reinforcement mesh was embedded through the concrete elements with full bond between the two. Continuum 2D shell elements (S4R) with an element size of $5 \mathrm{~mm}$ were used to model the CFRP material based on Table 5 . The bond between the CFRP and concrete was modelled using cohesive elements (COH3D8) with the adhesive layer being modelled using a single layer of cohesive elements of $5 \mathrm{~mm}$ element size. Debonding of the CFRP strips is represented by the onset of damage in the cohesive elements [27, 29]. Damage initiation is defined using a maximum nominal stress criterion as described by $[27,30,31]$. Fig. 6 shows the finite element mesh of the $1 / 4$ slab comprising 17304 concrete elements, 2220 cohesive elements and 2320 FRP elements.

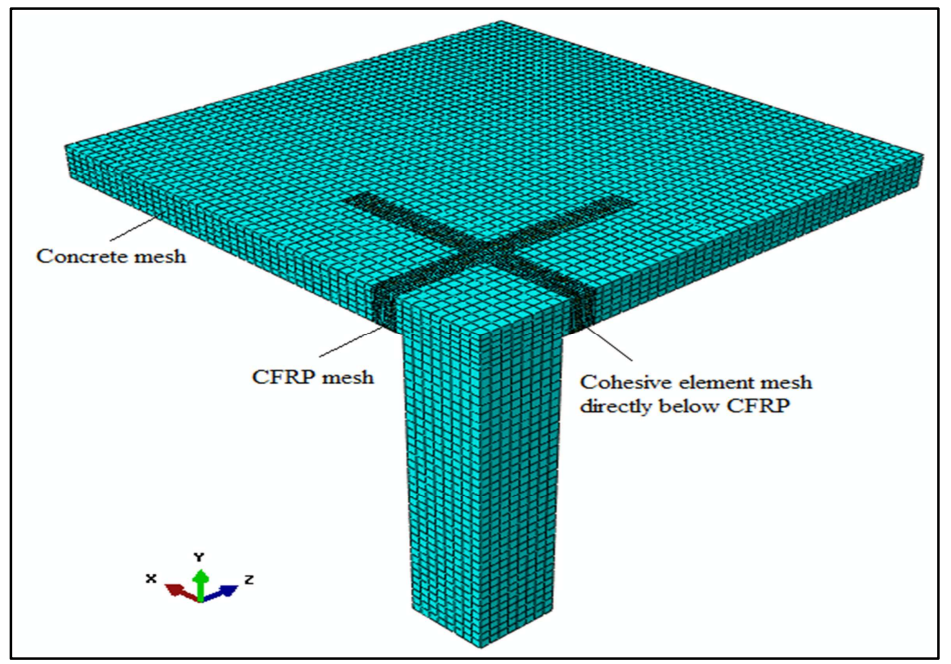

Fig. 6 Finite element mesh of the slab column connection

\section{Discussion of the Results}

The numerical and the experimental results are now discussed in detail in the following sections. Note that in the case of strengthened slabs 3 and 4, a numerical model of the corresponding un-strengthened slab with openings was also conducted for comparison. 


\subsection{Cracking and failure characteristics}

All the specimens in the experimental and numerical studies failed by punching shear with the inherent brittle characteristics but at different load levels based on the presence of CFRP as shown in Fig. 7 and Fig. 8. In all specimens, cracking was observed first on the top surface of the slab column connections close to the inner corner of the column which then propagated to the free edges of the slab; cracking was then observed in the lower surface of the slab at slightly higher loads. No cracking developed parallel to the diagonals of the slab. With increasing load, cracks propagated across the free edges following an inclined path away from the column edges culminating in torsional cracks and ultimately punching shear failure. Torsional moments are developed simultaneously with bending moments and shear forces when the external loads act transversely at a distance from the support column [32] as shown in Fig. 7.

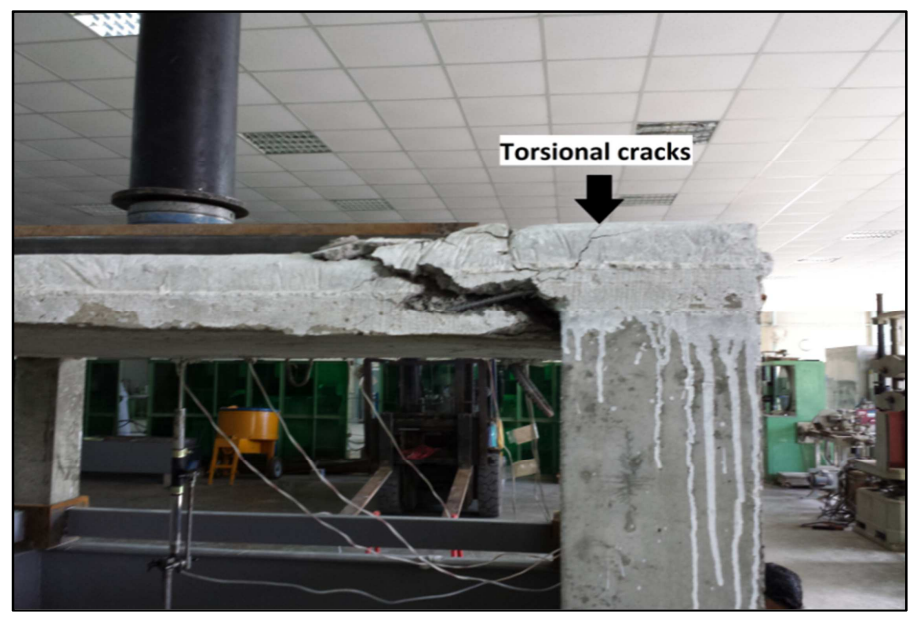

(a)

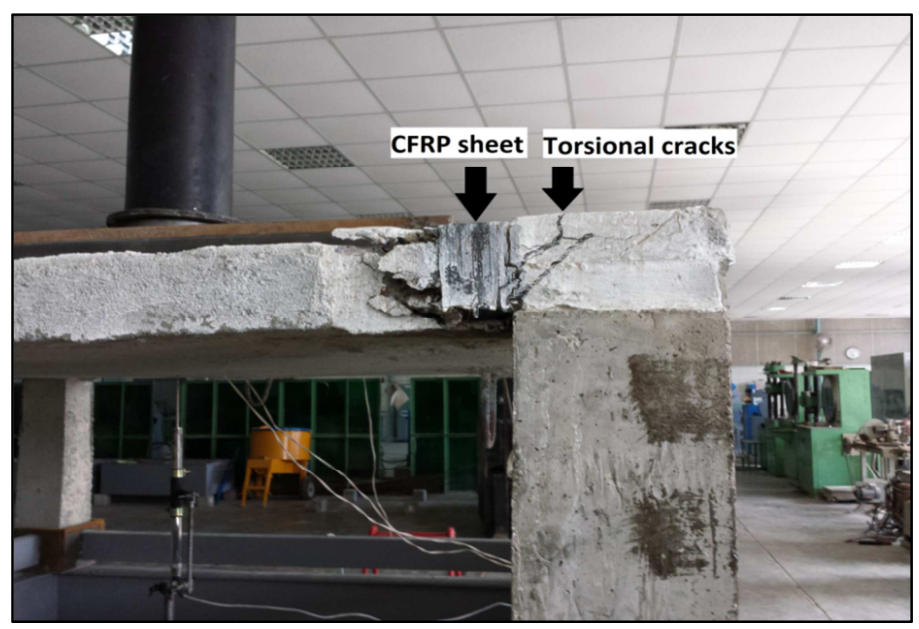

(b)

Fig. 7 Punching shear failure in (a) Slab 1 (b) Slab 2 
The typical inclination of punching shear cracks is shown in Fig. 7 for slabs 1 and 2. The tensile resistance of the CFRP sheets perpendicular to their longitudinal axis is small; therefore they will be less effective in resisting the corresponding tensile stresses and shear crack formation in that direction. In view of this, shear crack propagation away from the column face was approximately the same in both slabs. Based on these observations, it can be concluded that using CFRP reinforcement in these configurations has no major effect on the position of the punching shear crack as suggested by other researchers [33, 11,34], however the onset of cracking and its development can be delayed. In the concrete damage plasticity model adopted in ABAQUS, the direction of cracking is indicated by the maximum principal plastic strain [27]. Fig. 8 shows the maximum principal plastic strains at the slab column intersection of slab 1 at the ultimate punching load. It can be seen from the figure that the critical shear crack is formed at the intersection point of the slab to column zone, causing a reduction in the ability to carry the compression stresses to the column as described by Muttoni [9]. In slab 2, the CFRP sheets debonded from the concrete substrate near the shear crack after the peak load due to the relatively high vertical displacement across the shear crack as shown in Fig. 9. It should be noted up to ultimate load in the experiments, CFRP debonding did not occur in any of the strengthened slabs. Fig. 10 shows the numerical model stiffness degradation in the cohesive elements for slabs 2, 3 and 4 , revealing that the maximum stiffness degradation is globally less than 1.0 (where a value of 1.0 refers to the onset of debonding). Close examination of Fig. 10(a) indicates some localised areas are approaching debonding, particularly at the very edges of the CFRP along the sides of the slab which is consistent with the experimental behavior shown in Fig. 9.

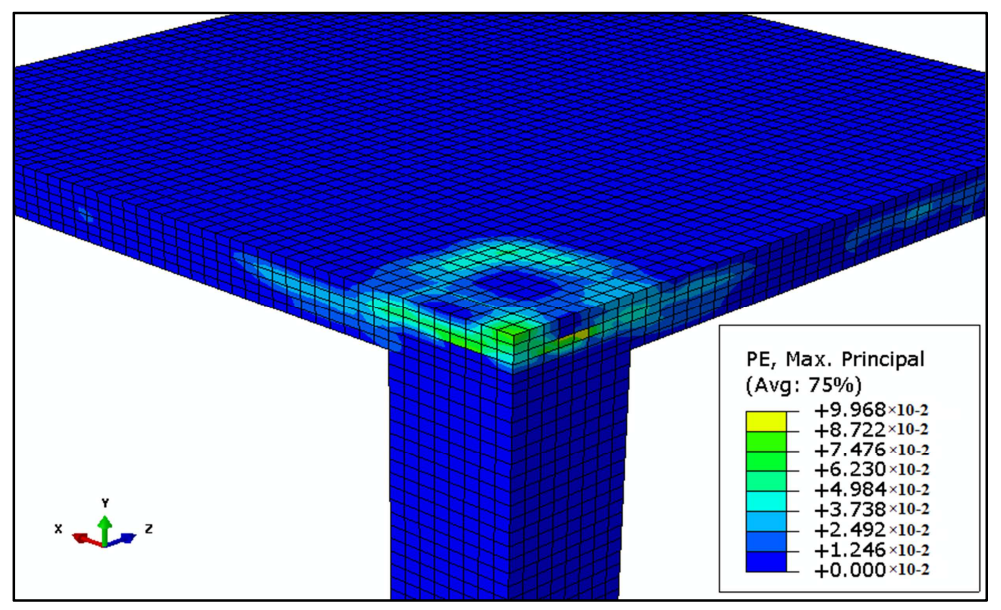

Fig. 8 Numerical model principal maximum plastic strain at peak load indicating punching shear failure in slab 1 


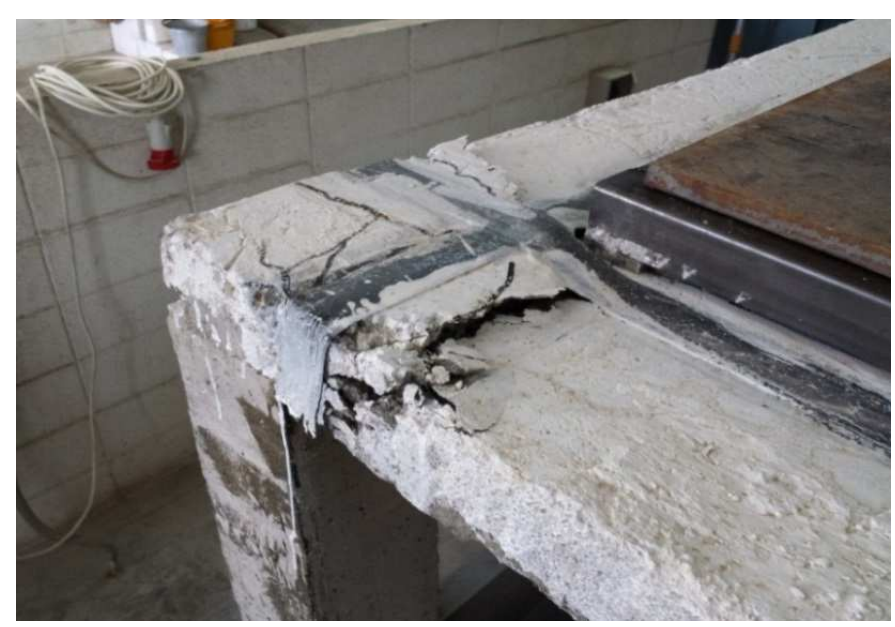

Fig. 9 Punching shear failure in Slab 2

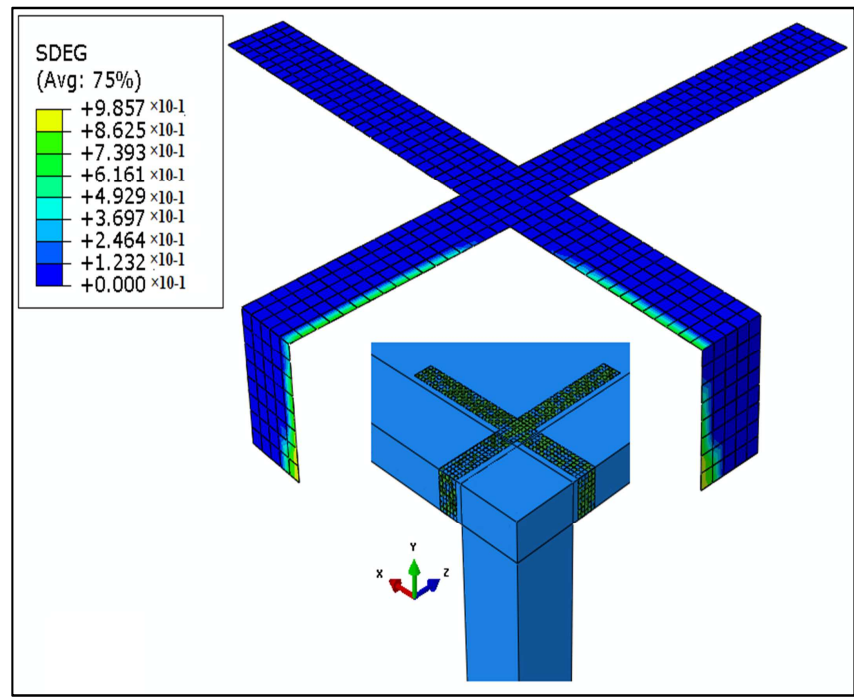

(a) Slab 2

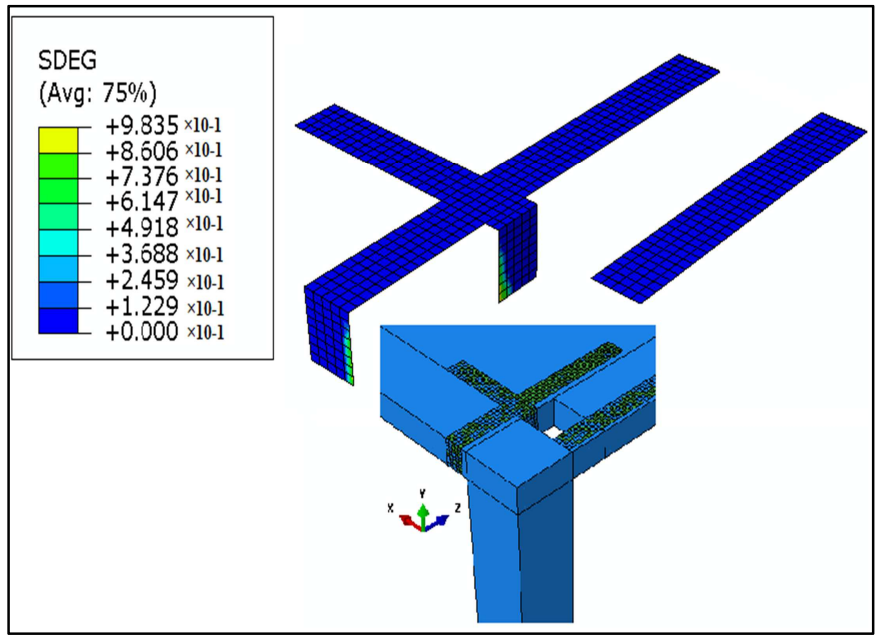

(b) Slabs 3 and 4

Fig. 10 Stiffness degradation in strengthened slabs 
Table 6 gives a summary of both the load at first cracking and ultimate load with the corresponding deflections and failure mode of the slabs in the experimental study. It can be seen that using CFRP has slightly delayed the onset of concrete cracking from $34.2 \mathrm{kN}$ to about $38.6 \mathrm{kN}$ for slab 2. This may in part be attributed to the improvement in rotational resistance provided by the CFRP sheets as they bridge across the diagonal shear crack and limit crack opening. Theoretically, decreasing the discontinuity caused by the slab rotation in the critical shear crack region would lead to a reduction of the overall mid-span deflection.

Table 6 Summary of experimental and numerical results

\begin{tabular}{|c|c|c|c|c|c|c|c|c|c|}
\hline \multirow{2}{*}{ slab } & \multicolumn{2}{|c|}{$\begin{array}{c}\text { Load at first } \\
\text { cracking }(\mathrm{kN})\end{array}$} & \multicolumn{2}{|c|}{$\begin{array}{c}\text { Mid-span } \\
\text { deflection at } \\
\text { first cracking } \\
(\mathrm{mm})\end{array}$} & \multicolumn{2}{|c|}{$\begin{array}{c}\text { Ultimate load } \\
(\mathrm{kN})\end{array}$} & $\begin{array}{c}\text { Ultimate mid- } \\
\text { span } \\
\text { deflection } \\
(\mathrm{mm})\end{array}$ & $\begin{array}{c}\text { Numerical } \\
\text { Failure } \\
\text { Mode }\end{array}$ \\
\cline { 2 - 9 } & Exp. & Num. & Exp. & Num. & Exp. & Num. & Exp. & Num. & \\
\hline 1 & 34.2 & 37.3 & 1.2 & 0.9 & 127.4 & 128.7 & 33.8 & 38.8 & Punching \\
\hline 2 & 38.6 & 41.1 & 1.0 & 1.1 & 141.2 & 141.1 & 46.5 & 42.2 & Punching \\
\hline 3 & 33.2 & 36.8 & 1.4 & 1.2 & 109.8 & 111.8 & 32.9 & 30.7 & Punching \\
\hline 4 & 31.6 & 36.8 & 1.9 & 1.2 & 125.9 & 111.8 & 41.2 & 30.7 & Punching \\
\hline
\end{tabular}

\subsection{Load-deflection behaviour}

The load-deflection curves measured at the slab centre in the experiments and those from the numerical simulation are presented in Fig. 11. For the case of slabs 1and 2, it is noticed that the numerical model gives reasonable agreement with the experimental results. In both slab cases, the numerical model over-predicts the point of initial cracking. The difference in the pre-crack elastic behaviour may be partially due to the variation in the tensile strength and Young's modulus in the specimen compared to the properties adopted from the cylinder test. Similarly, the full bond assumption for rebar in the numerical model may lead to a stiffer response in the pre-crack regime [35].

For slab 2, the external CFRP reinforcement bridges the discontinuity at the critical crack region leading to a small reduction in the slab central deflection compared to slab 1 at the same load level. The presence of the CFRP ultimately led to a modest increase in peak load and deflection. Despite the presence of strengthening, the propagation of the shear crack is approximately the same in both slabs 1 and 2 as shown in Fig. 7. 
The same general behaviour was also seen in slabs 3 and 4. The cracking load is less than that of slab 1 where the existence of the opening affected the total stiffness and ultimate strength of the slabs. Small differences between the numerical models in both the strengthened and un-strengthened cases are observed in the ultimate strength and deflection. For the experimental cases, there are some differences between the ultimate load and deflection. The general behaviour is similar with both slabs failing in the same manner.

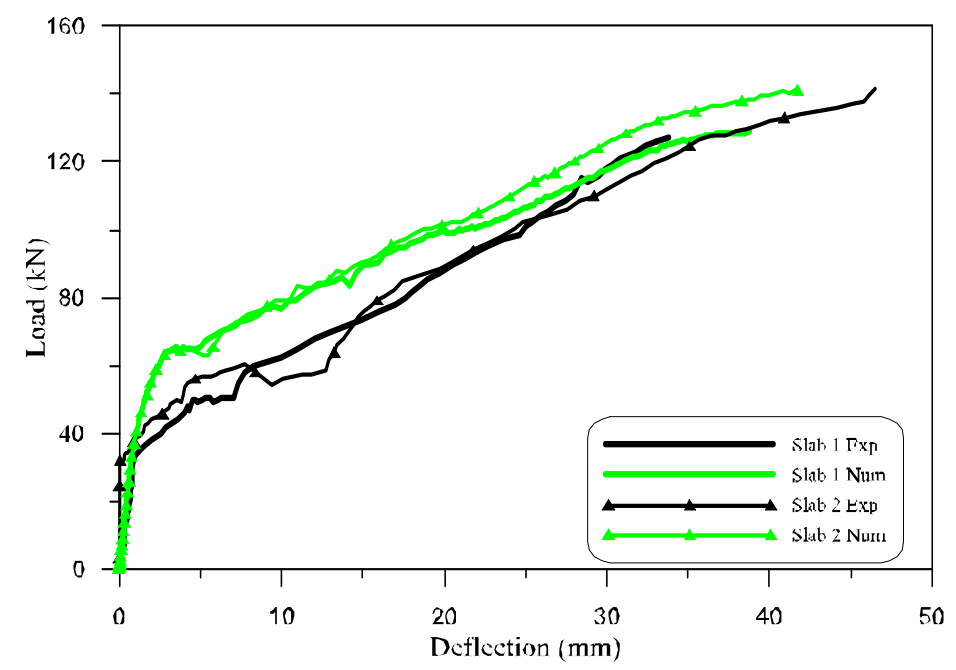

(a) Slabs 1,2

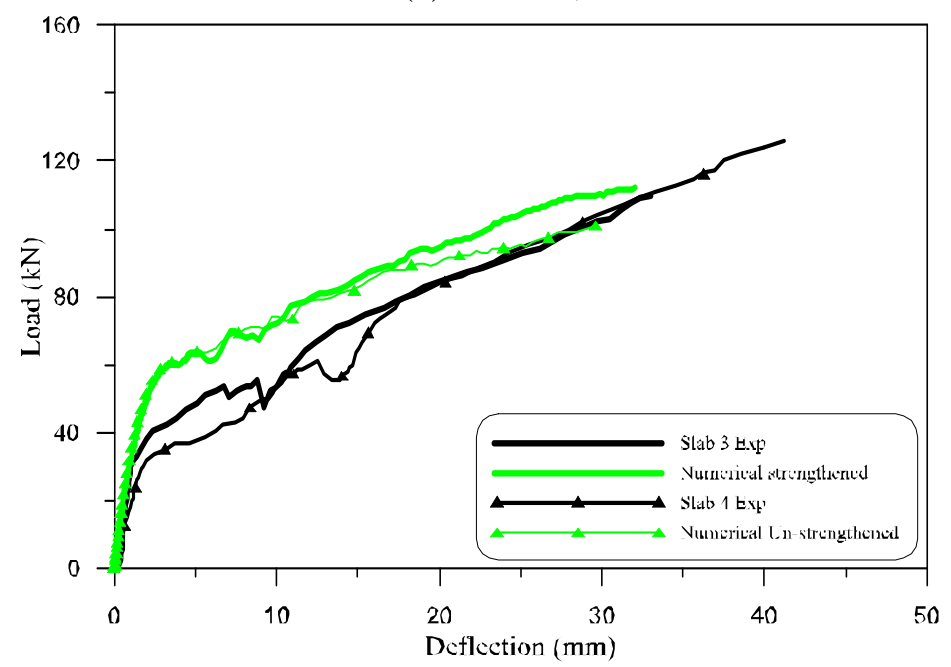

(b) Slabs 3, 4

Fig. 11 Load vs. mid-span deflection

The behaviour of each specimen can be usefully characterised in terms of the increase in both the ultimate strength and deflection. It is found that strengthening slab 2 by CFRP reinforcement increased both the ultimate punching shear capacity $(\sim 11 \%)$ and deflection $(\sim$ 
$40 \%$ ) as observed. For slabs 3 and 4, the increases in the ultimate load were $10 \%$ and $23 \%$ respectively compared to the numerical model of the un-strengthened slab with openings.

Similar levels of ultimate load enhancement have been observed for the case of internal column slab connections with comparable top rebar \% (in this case $0.25 \%$ in each direction), as outlined in Table 1 and described by Faria et al [36].

\subsection{Reinforcement strains}

\subsubsection{Steel strains in slabs 1 and 2}

Fig. 12 shows a comparison between the experimental and the numerical results for the strains in the rebar for both the un-strengthened and strengthened slabs.

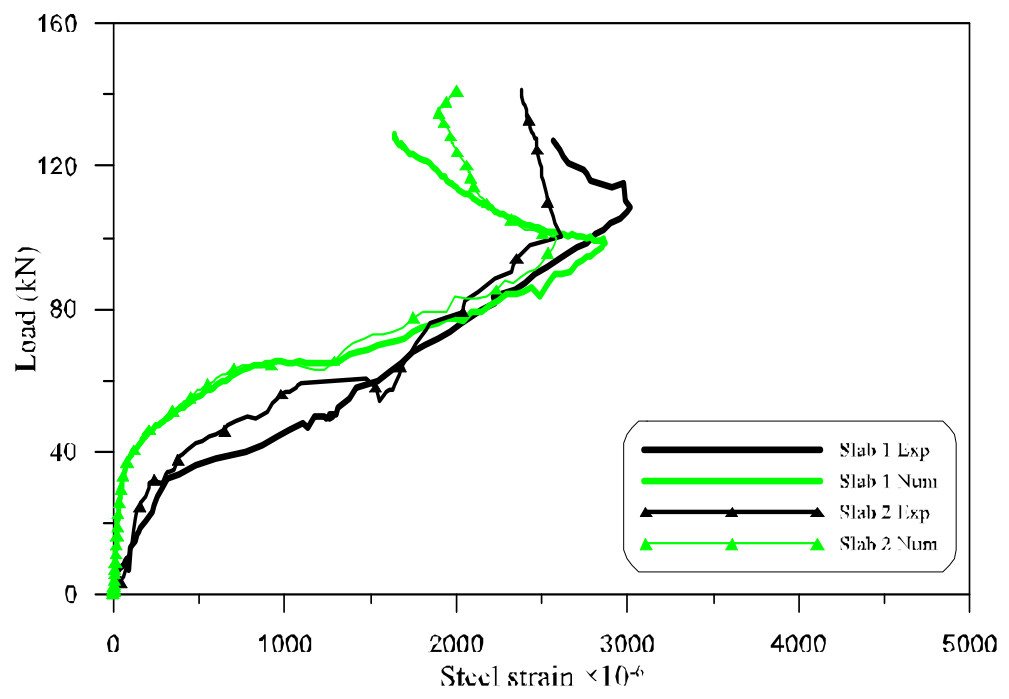

(a) Strain gauge 2

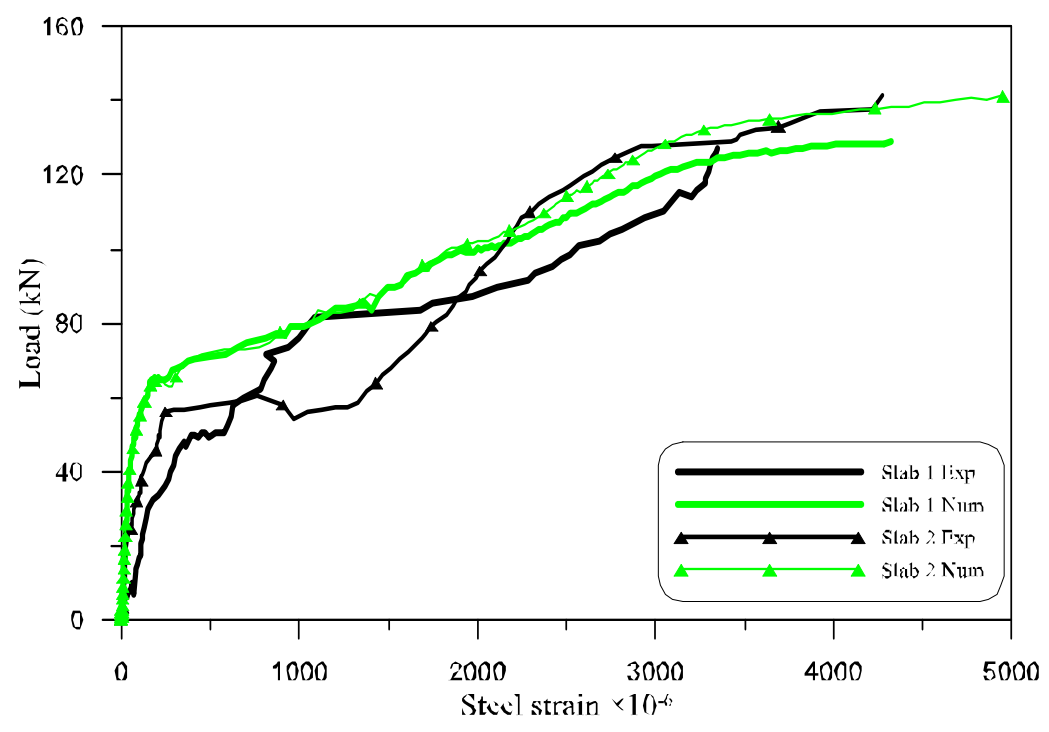

(b) Strain gauge 4 


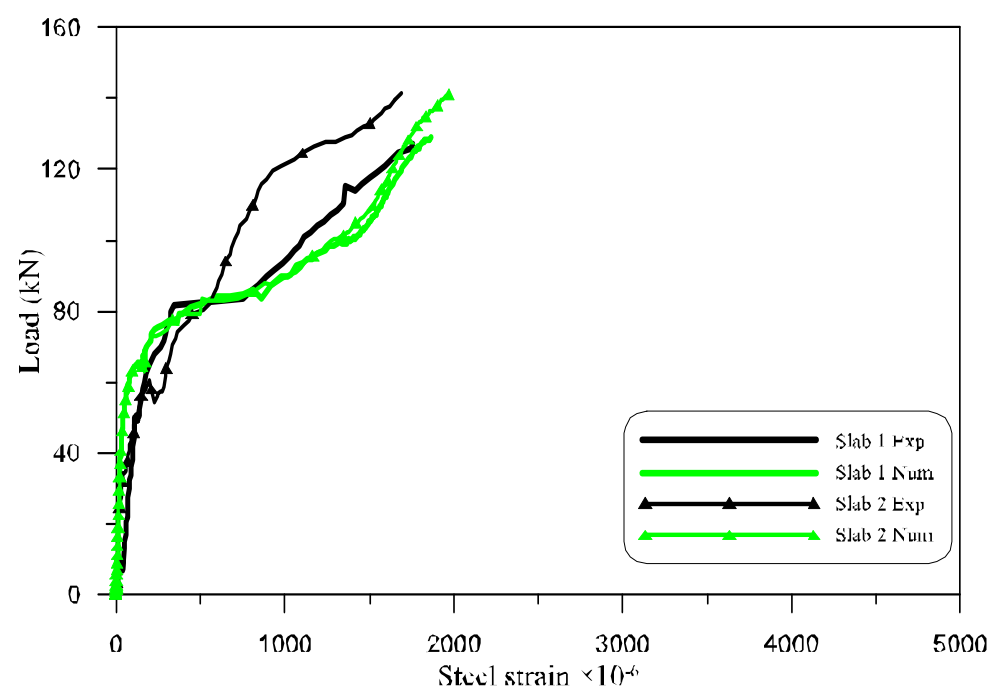

(c) Strain gauge 6

Fig. 12 Steel reinforcement strains in slabs 1 and 2

Parts of the rebar in the top mesh over the columns reach yield strain (3000 micro strain) before the punching shear failure takes place. This is common in punching shear scenarios where prior yielding of the rebar occurs locally around the column [37]. In the experiment, strains at gauge 2 and the corresponding position in the numerical model showed a reduction at a load level of $107 \mathrm{kN}$ before failure as shown in Fig. 12(a). A possible explanation is that concrete crushing in the compression zone has initiated and this causes a redistribution of strains in this area. This is confirmed in the numerical model which indicates the concrete compressive strength has been reached at a similar load level as shown in Fig. 13 (note the column was removed for clarity to show the stress distribution through the slab thickness). In both slabs 1 and 2, strain gauge 4 recorded yield at nearly the ultimate load, while strain gauge 6 showed yield had not yet occurred. 


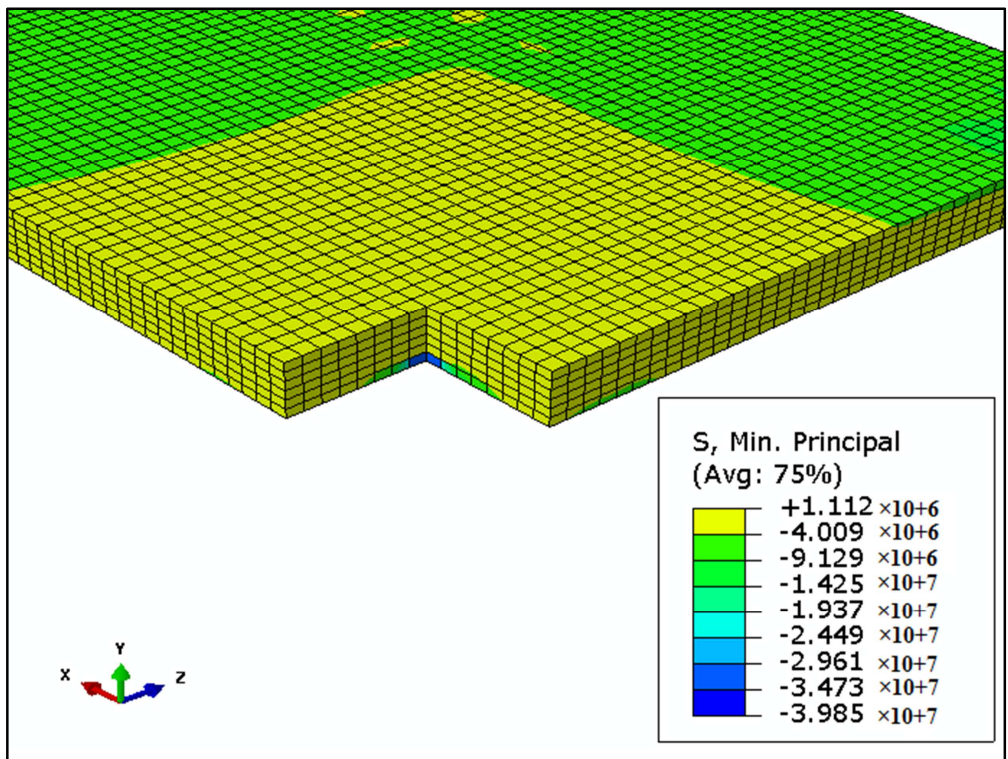

Figure 13 Minimum principal stresses in the concrete $\left(\mathrm{N} / \mathrm{m}^{2}\right)$ at load level $96 \mathrm{kN}$

\subsubsection{CFRP strains in slab 2}

Fig. 14 shows the strains in the CFRP reinforcement from both the experiment and the numerical model. Strains were measured adjacent to the interior column corner where maximum biaxial bending moments are expected. It is seen that all the strain measurements have an approximately horizontal shift at a load level of about $125 \mathrm{kN}$ which indicates that the shear crack has passed the location of the strain gauges. The maximum strain in the CFRP occurs at the slab edges based on the numerical results, as seen in Fig. 14. The maximum strains in the numerical model are around $11 \%$ of the rupture strain (as in FSG2) which is close to the strains in the corresponding location in the experiment. 


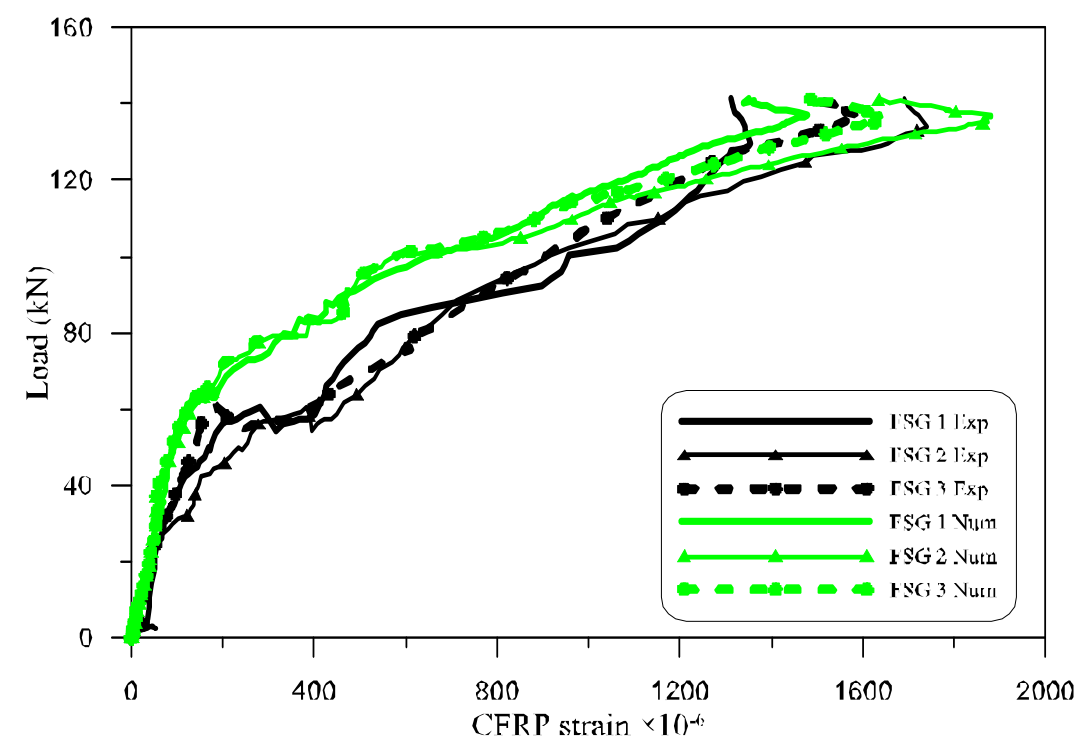

Fig. 14 CFRP reinforcement strain reading for slab 2

Fig. 15 shows the maximum principal stresses in the CFRP sheet at first cracking and ultimate load. At onset of cracking, it can be seen that the maximum stresses occur close to the inner corner of the column where concrete cracking initiates, while stresses decrease towards the slab centre in line with the distribution of moments. At failure, the opening of the punching shear crack and associated increase in rotation causes an increase in maximum principal stresses in the CFRP, particularly around the edge of the slab where a greater degree of mobilisation can be observed. As previously mentioned, on examination of Fig. 10(a) the numerical model suggests this same area is where debonding would most likely occur (i.e. the zone with the highest damage parameter).

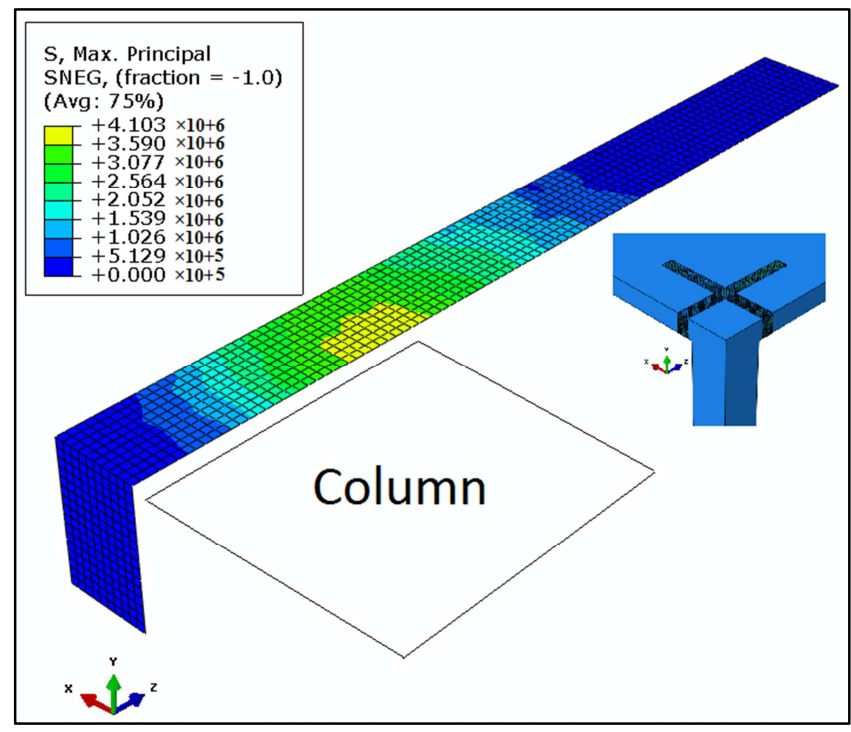

(a) Load at first cracking 


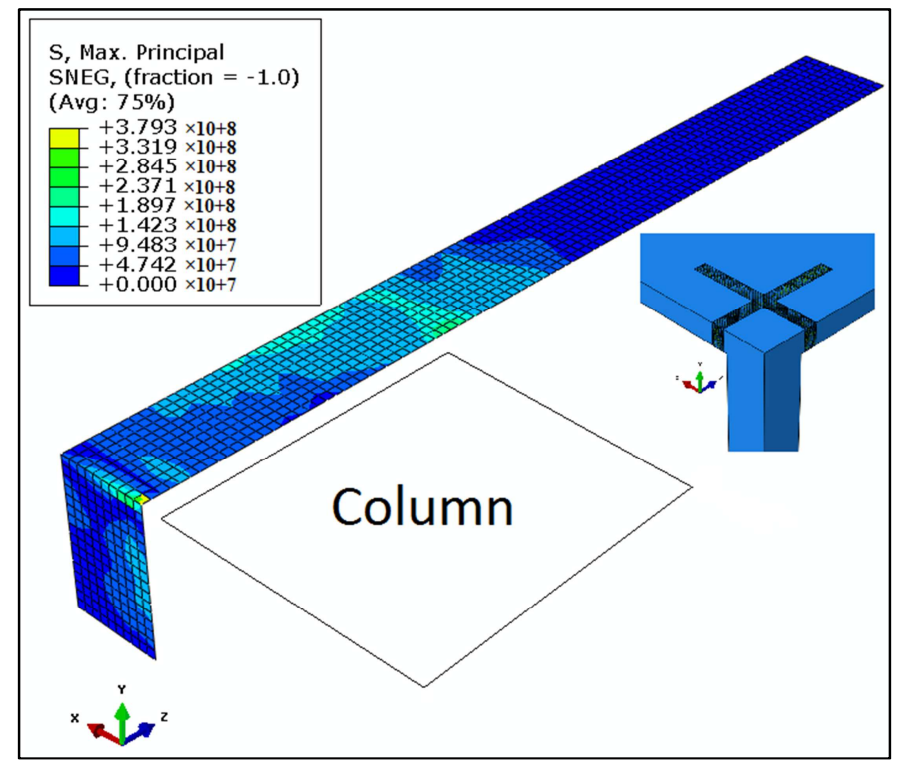

(b) Ultimate load

Fig. 15 Maximum principal stress in CFRP $\left(\mathrm{N} / \mathrm{m}^{2}\right)$

\subsubsection{Steel strains in slabs 3 and 4}

The existence of the opening reduces the load at first cracking compared to that in slab 1. Due to the CFRP strengthening, cracking can be delayed up to a load approximately equal to the cracking load of slab 1 as shown in Fig. 16. It is also seen from Fig. 16 that the steel reinforcement over the column incurs less strains as compared to the reinforcement in slab 1 as shown in Fig. 12 because the existence of the opening has reduced the total ultimate load. An approximately similar reduction in the steel reinforcement was also shown in Fig. 16 due to the initiation of concrete crushing as discussed previously for slabs 1 and 2 . 


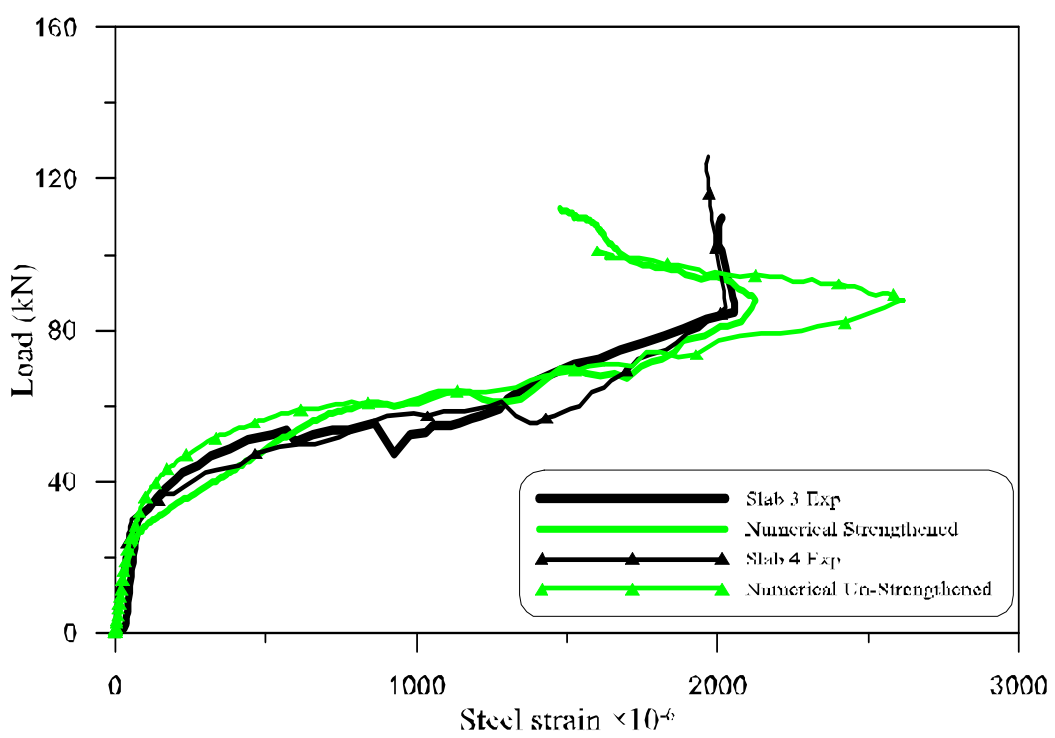

(a) Strain gauge 2

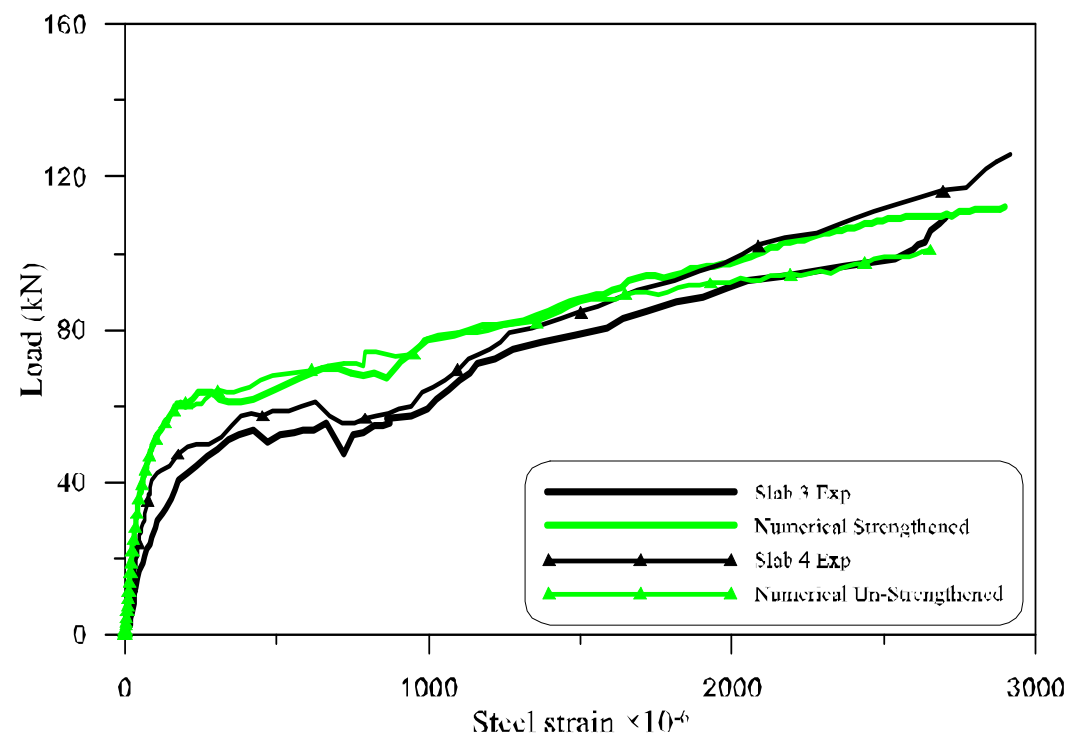

(b) Strain gauge 4 


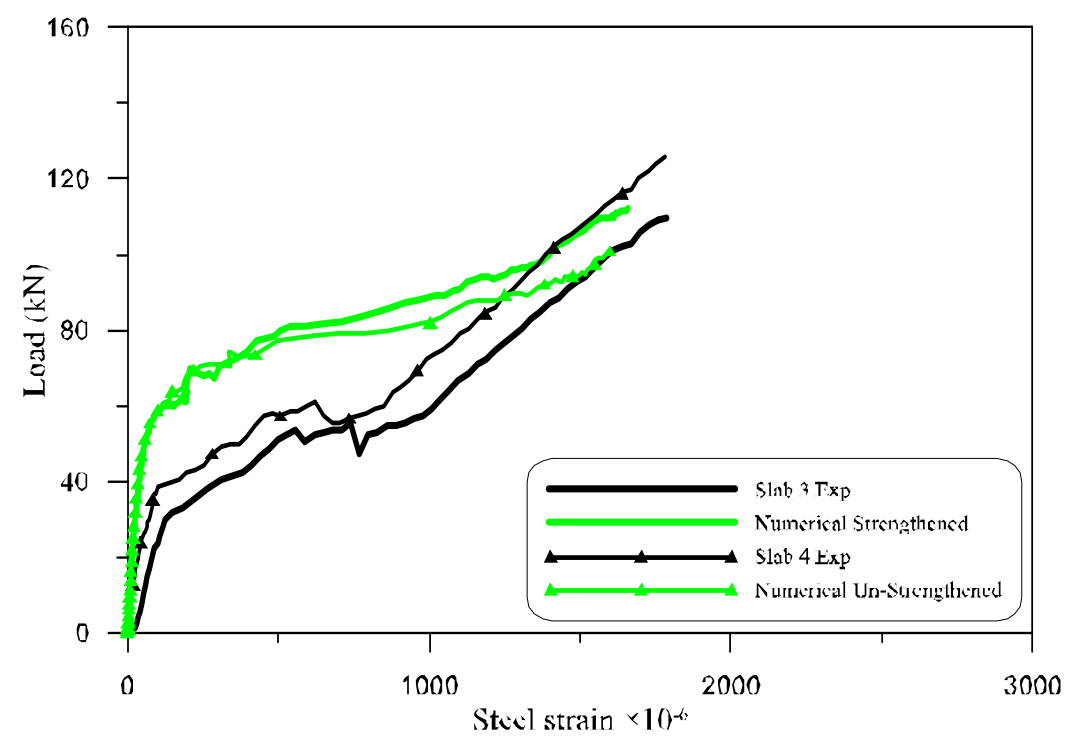

(c) Strain gauge 6

Fig. 16 Steel reinforcement strains for slab 3 and 4

\subsubsection{CFRP strains in slabs 3 and 4}

It is seen from Fig. 17 that the maximum strain in the CFRP does not reach the ultimate tensile strain or the rupture strain of 0.017. At the early stages of loading, FSG 1 and FSG 2 recorded more strains than FSG 3 because cracks are initially developed near the interior corner of the column. With increasing load, more cracks developed in the concrete around the opening. At this stage, FSG 3 gives the maximum strain in the CFRP sheets due to further crack development in that region. At failure, it was seen that the diagonal cracking passes through the high stress concentration zone between the opening and the slab edge below FSG 3, as shown in Fig. 18, thus giving the high strain reading in FSG3.

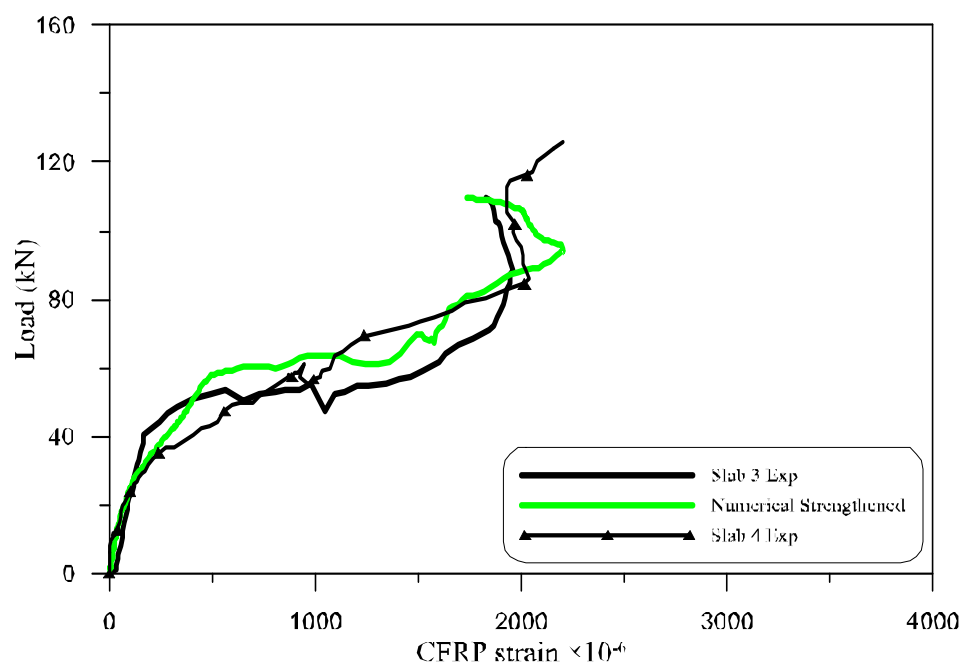

(a) CFRP strain gauge FSG1 


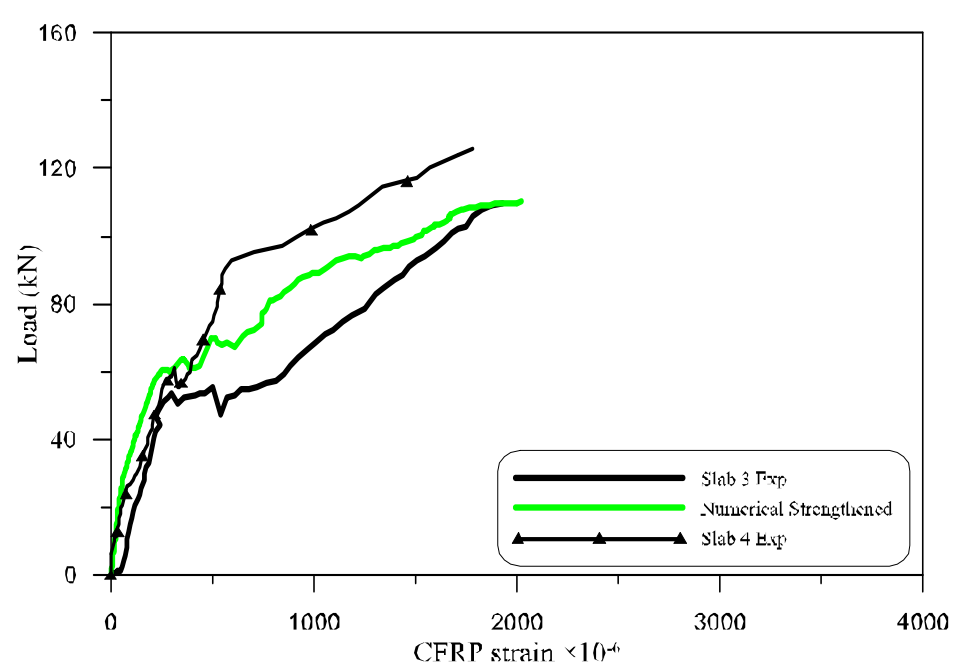

(b) CFRP strain gauge FSG2

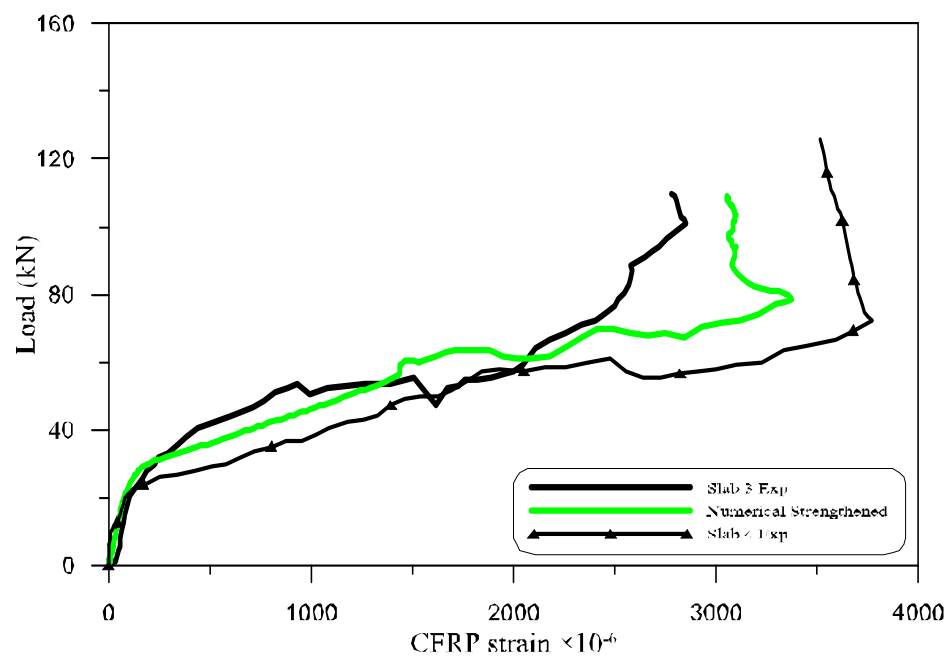

(c) CFRP strain gauge FSG3

Figure 17 CFRP reinforcement strains for slabs 3 and 4

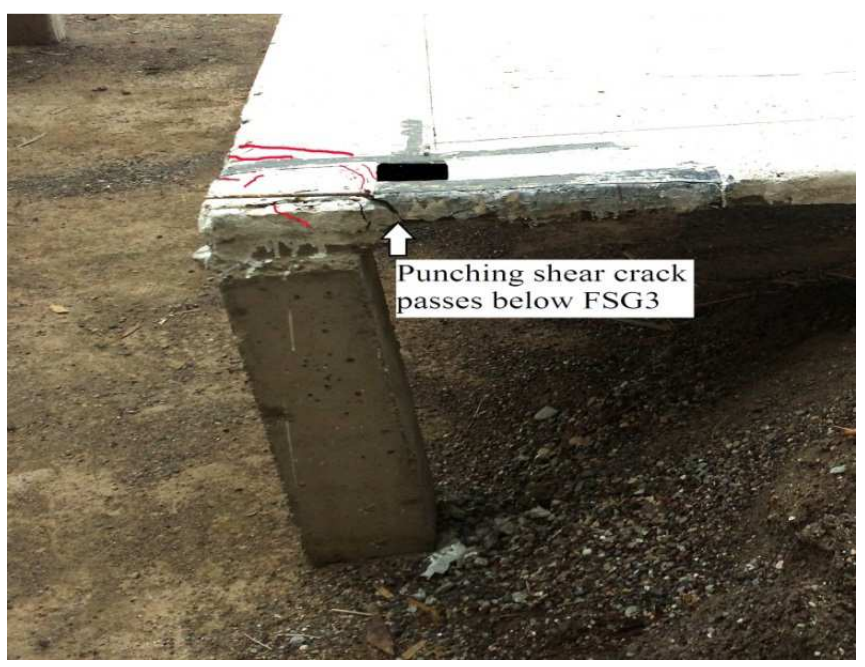

Fig. 18 Punching shear crack in slabs with openings 
Fig. 19 shows the distribution of the maximum principal stresses in the CFRP sheet at first cracking and ultimate load. At both stages it can be seen that the CFRP is working harder than in slab 2 as a result of the presence of the opening and associated increased stress concentration in the column-slab zone.

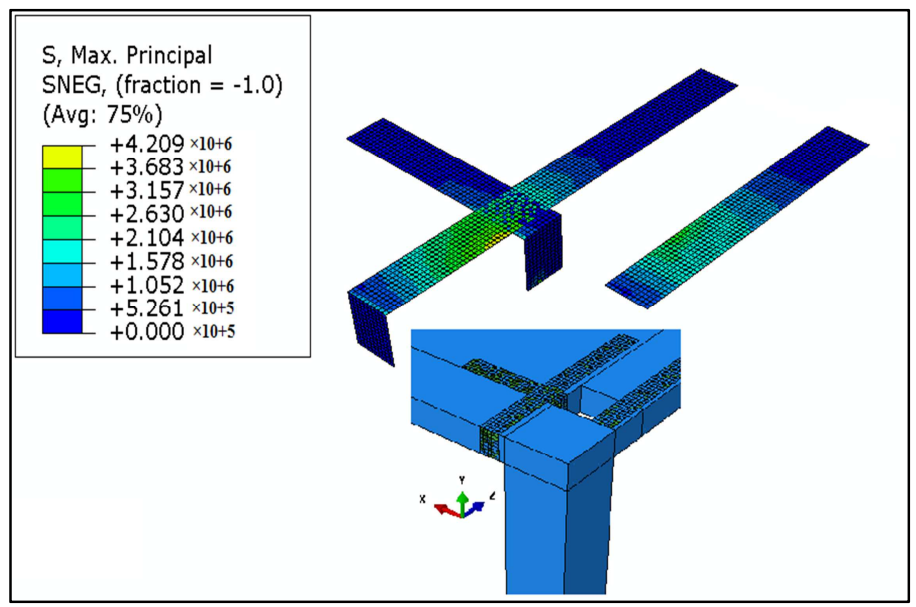

(a) Load at first cracking

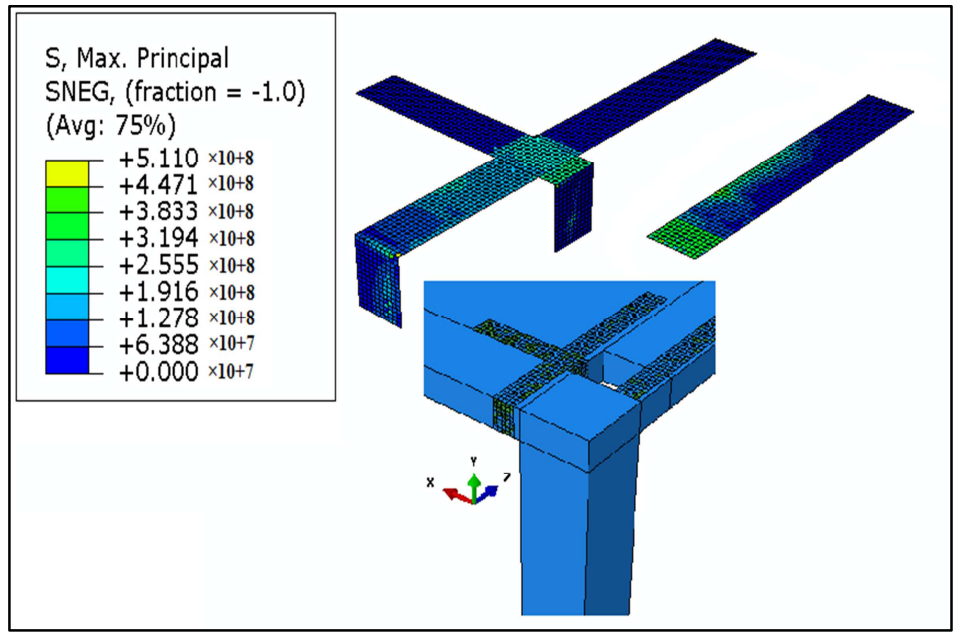

(b) Ultimate load

Fig. 19 Maximum principal stress in CFRP $\left(\mathrm{N} / \mathrm{m}^{2}\right)$

\section{Parametric Study on Strengthening Layout}

In the case of slabs 2 and 4 the level of load capacity enhancement via the indirect strengthening system has been modest. Similarly, no appreciable improvement in ductility has been observed. In this section, a number of alternative strengthening configurations are explored numerically (using slab 1 as the baseline) with a view to obtaining greater enhancements. Each alternative configuration (summarised in table 7) has been derived based on practical constraints associated with accessing the slab in real structures. One alternative 
configuration consists of applying the CFRP strips diagonally across the crack zone, this presents the opportunity to form a complete loop from top to bottom. The second alternative configuration comprises application of CFRP strips longitudinally along the exposed sides of the slab.

Table 7 Summary of Strengthening Arrangements

\begin{tabular}{|c|c|c|}
\hline Arrangement & Slab & Description \\
\hline & $\mathrm{Ai}$ & $\begin{array}{l}1 \text { diagonal CFRP sheet on the top surface only, } \\
\text { no longitudinal side strengthening }\end{array}$ \\
\hline & Aii & $\begin{array}{l}\text { Continuous diagonal CFRP sheet on the top,side } \\
\text { and bottom surface, no side longitundinal } \\
\text { strengthening }\end{array}$ \\
\hline & $\mathrm{Ci}$ & $\mathrm{Ai}+$ longitudinal side strengthening \\
\hline & Cii & Aii + longitundinal side strengthening \\
\hline & $\mathrm{Bi}$ & $\begin{array}{l}\text { Orthogonal CFRP on the top and side (as per } \\
\text { Slab 2), no longitudinal side strengthening }\end{array}$ \\
\hline & Bii & $\begin{array}{l}\text { Orthogonal CFRP on the top, side and botton, } \\
\text { no longitudinal side strengthening }\end{array}$ \\
\hline & Ciii & $\mathrm{Bi}+$ longitudinal side strengthening \\
\hline & Civ & Bii + longitudinal side strengthening \\
\hline \multicolumn{3}{|c|}{$\begin{array}{l}\text { Notes: } \\
\text { 1. All CFRP sheets } 50 \mathrm{~mm} \text { wide } x 0.8 \mathrm{~mm} \text { thickness (properties as per slab 2) } \\
\text { 2. Side CFRP is placed along the mid-plane of the slab } \\
\text { 3. } \mathrm{L}=320 \mathrm{~mm}, \mathrm{~L}_{1}=500 \mathrm{~mm}\end{array}$} \\
\hline
\end{tabular}

The load vs. central displacement plots for each configuration is shown in figure 20. In all cases, the slabs failed in punching shear in a similar manner to slab 2, with no occurrence of debonding. From figure 20a) it can be observed that the diagonal strip configurations produced an almost identical performance to slab 2. It is worth noting that the $\mathrm{Ai}$ configuration uses the least amount of CFRP, however this also results in a slight reduction in ductility. It is also interesting to note that application of strengthening to the bottom face in combination to the top face has no real effect, whether a diagonal or orthogonal configuration is adopted, this is reflective of the moment regime at the corner column zone. The only notable load enhancement occurred with the Ciii \& Civ configurations although both cases resulted in a stiffer response and a corresponding reduction in ductility, see figure 20b). Additionally it can be observed that application of longitudinal strengthening to the exposed sides of the slabs also results in small load enhancement in all cases as shown by the performance of the $\mathrm{C}$ series globally. 


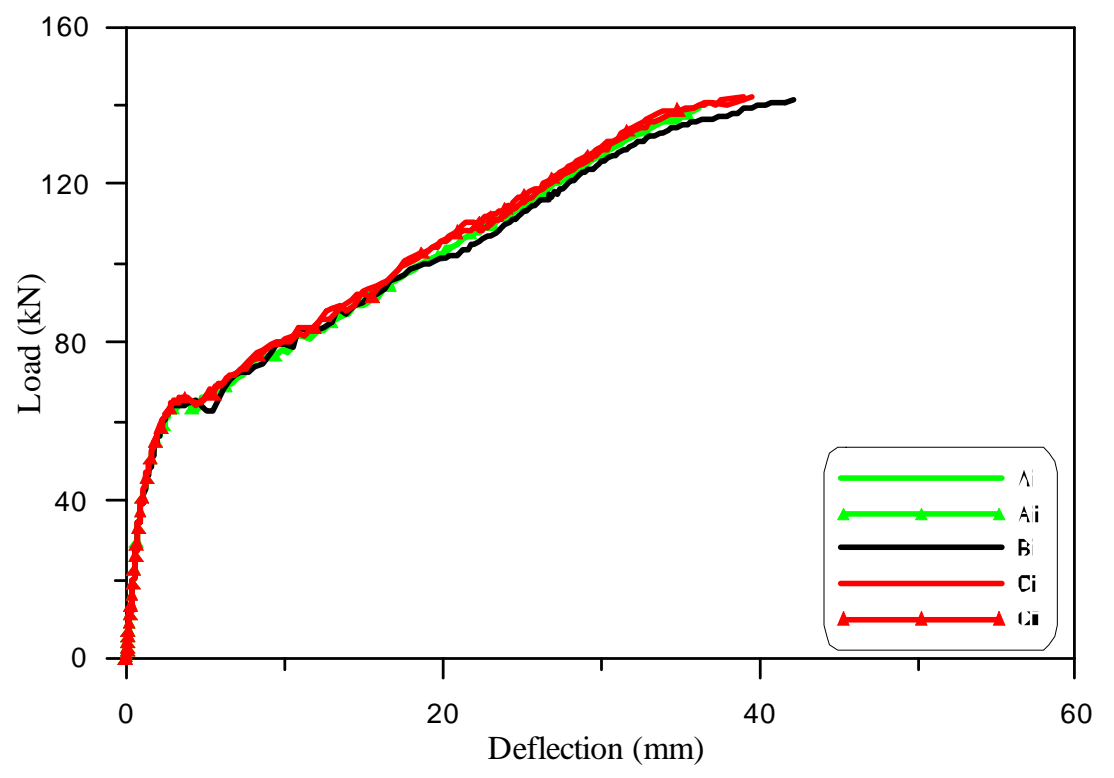

(a) Diagonal configurations

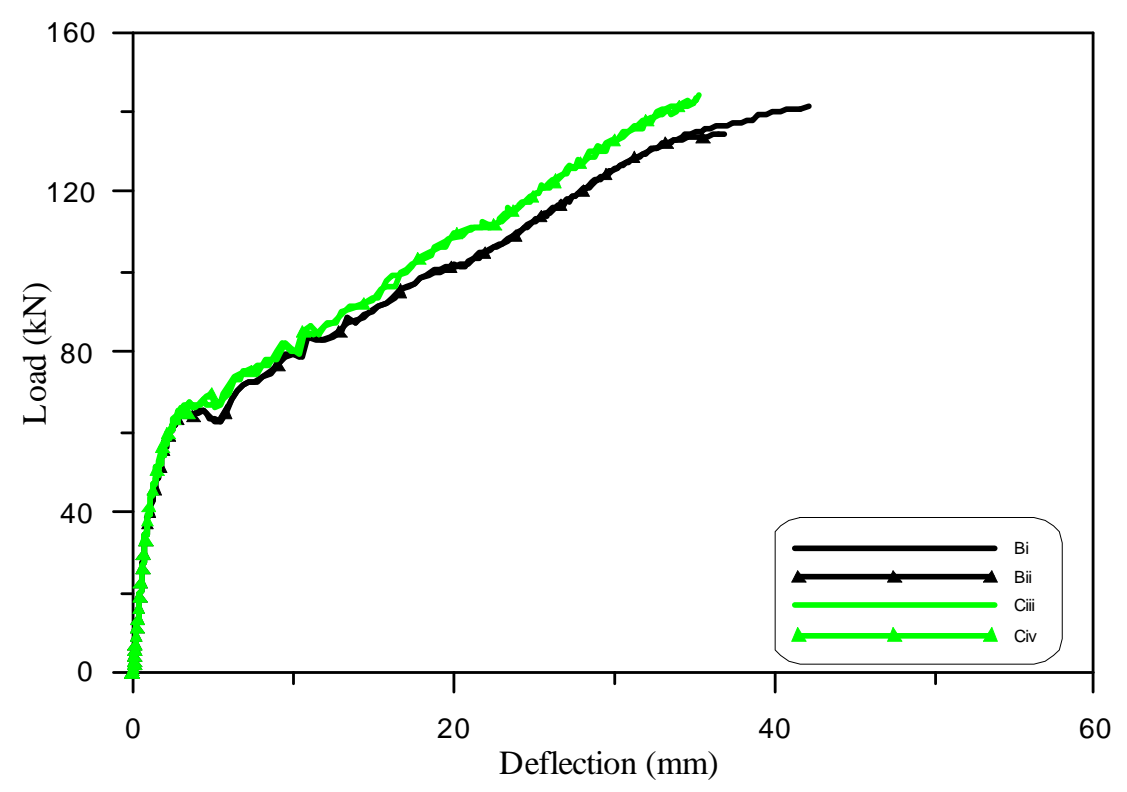

(b) Orthogonal configuration

Fig. 20 Numerical Load vs. Central Deflection a) diagonal configurations, b) orthogonal configuration

\section{Conclusions}

The aim of using CFRP strengthening at the column-slab zone is to increase punching shear capacity. Ideally, the use of CFRP should cause a more ductile response from the slab. Depending on the CFRP strengthening configuration, it may be the case that a less ductile response incurs, even though an increase in overall load is achieved. Based on the current studies, the most important concluded points are: 
1- Strengthening corner slabs by surface mounted CFRP strips resulted in delaying the initiation of the flexural cracks in slabs. This delay has improved the slab performance by increasing the total ultimate loading capacity of slab 2 from $127.4 \mathrm{kN}$ to $141.2 \mathrm{kN}$ and the sustained deflection from 33 to $46 \mathrm{~mm}$.

2- The externally bonded CFRP sheets reduced the total strain in the internal steel bars over the column region.

3- The steel tensile strains increased in the slab centre due to the increase in the deformation and ultimate load capacity.

4- The strengthened slab column connections have a stiffer behaviour than the un-strengthened slabs because the CFRP delays the initiation of cracking.

5- The existence of the opening reduced the ultimate punching shear capacity. Strengthening with CFRP allowed the slab to recover the ultimate punching shear capacity to a level commensurate with the slab without openings.

6- In all strengthened slab systems examined, the CFRP stresses were comparatively low at ultimate load; similarly the load enhancement achieved by strengthening was also relatively small. This highlights the limitations of achievable enhancement with the method, increasing CFRP amount is unlikely to result in significant load enhancements or be economic. Greater enhancements may be achievable where the top steel rebar \% is small as outlined by Faria et al [36]. In general, the technique remains applicable to corner slab zones in areas where small load enhancements are of benefit.

\section{Acknowledgments}

Our thanks are due to 'The Ministry of Higher Education and Scientific Research-Kurdistan Regional Government-Iraq' for funding this research. Special thanks are extended to Professor Dr Omar Qarani Aziz for his co-supervision during the experimental phase of this work and the technical staff at the Civil Engineering department, College of Engineering, University of Salahaddin-Erbil-Iraq for their assistance. We are grateful for the continuous support of the School of Mechanical, Aerospace and Civil Engineering, University of Manchester, throughout this research project.

\section{References}


[1] Li, R., Young, S. C. and Zhang, S. (2007). Punching shear behaviour of concrete flat plate slab reinforced with carbon fibre reinforced polymer rods. Composites Part B: Engineering, 38(5), pp.712-719.

[2] Ebead, U. and Marzouk, H. (2004). Fibre reinforced polymer strengthening of two-way slabs. ACI Structural Journal, 101(5), pp. 650-659.

[3] Durucan, C. and Anil, Ö. (2015). Effect of opening size and location on the punching shear behaviour of interior slab-column connections strengthened with CFRP strips. Engineering Structures, 105, pp. 22-36.

[4] Sissakis, K. and Sheikh, S.A. (2000). The use of CFRP strands to improve the punching shear resistance of concrete slabs. PhD Thesis. University of Toronto.

[4] Gouda, A. and El-Salakawy, E. (2016). Behavior of GFRP-RC Interior Slab-Column Connections with Shear Studs and High-Moment Transfer. ASCE Journal of Composites for Construction, 20(4), pp. 040160051-0401600512.

[5] Sissakis, K. and Sheikh, S.A. (2007). Strengthening concrete slabs for punching shear with carbon fibre-reinforced polymer laminates. ACI Structural Journal, 104(1), pp. 49-59.

[6] Binici, B. and Bayrak, O. (2003). Punching shear strengthening of reinforced concrete flat plates using carbon fibre reinforced polymers. Journal of Structural Engineering, 129(9), pp.1173-1182.

[7] Meisami, M. H., Mostofinejad, D. and Nakamura, H. (2013). Punching shear strengthening of two-way flat slabs using CFRP rods. Composite Structures, 99, pp. 112-122. [8] Erdogan, H., Binici, B. and Ozcebe, G. (2010). Punching shear strengthening of flat-slabs with CFRP dowels. Magazine of Concrete Research, 62(7), pp. 465-478.

[9] Muttoni, A. (2008). Punching shear strength of reinforced concrete slabs without transverse reinforcement. ACI Structural Journal, 105, pp. 440-450.

[10] Erki, M. A. and Heffernan, P. J. (1995). Reinforced concrete slabs externally strengthened with fibre-reinforced plastic materials. In: RILEM Proceedings, CHAPMAN and HALL, pp. 509-509.

[11] El-Salakawy, E., Soudki, K. and Polak, M. A. (2004). Punching shear behaviour of flat slabs strengthened with fibre reinforced polymer laminates. Journal of Composites for Construction, 8(5), pp. 384-392.

[12] Sharaf, M. H., Soudki, K. A. and Michael, V. D. (2006). CFRP strengthening for punching shear of interior slab-column connections. Journal of Composites for Construction, 10(5), pp. 410-418. 
[13] Desayi, P. and Seshadri, H. K. (1997). Punching shear strength of flat slab corner column connections. Part1. Reinforced Concrete Connections. Proceedings of the Institution of Civil Engineers, Structures and Buildings, 122(1), pp. 10-20.

[14] Walker, P. R. and Regan, P. E. (1987). Corner column-slab connections in concrete flat plates. Journal of Structural Engineering, 113(4), pp.704-720.

[15] Binici, B. and Bayrak, O. (2005). Use of fibre-reinforced polymers in slab-column connection upgrades. ACI Structural Journal, 102(1), pp. 93-102.

[16] Binici, B. and Bayrak, O. (2005). Upgrading of slab-column connections using fibre reinforced polymers. Engineering Structures, 27(1), pp.97-107.

[17] Meisami, M. H., Mostofinejad, D and Nakamura, H. (2015). Strengthening of flat slabs with FRP fan for punching shear. Composite Structures, 119, pp. 305-314.

[18] Urban, T. and Tarka, J. (2010). Strengthening of slab-column connections with CFRP strips. Archives of Civil Engineering, 56(2), pp. 193-212.

[19] Abdullah, A., Bailey, C. G. and Wu, Z. J. (2013). Tests investigating the punching shear of a column-slab connection strengthened with non-prestressed or prestressed FRP plates. Construction and Building Materials, 48, pp. 1134-1144.

[20] Koppitz, R., Kenel, A. and Keller, T. (2014). Punching shear strengthening of flat slabs using prestressed carbon fibre-reinforced polymer straps. Engineering Structures, 76, pp. 283294.

[21] British Standards Institution (BSI), (2004), Eurocode 2: Design of concrete structures Part 1-1: General rules and rules for buildings.

[22] El-Salakawy, E. F., Polak, M. A. and Soliman, M. H. (2000). Reinforced concrete slabcolumn edge connections with shear studs, Canadian Journal of Civil Engineering, 27(2), pp. 338-348.

[23] ACI committee 440-2R. Guide for the design and construction of externally bonded FRP systems for strengthening concrete structures. ACI 440.2R-08, (2008). American Concrete Institute, Farmington Hills.

[24] Easycomposites Ltd. (2015). http://www.easycomposites.co.uk/

[25] Concrete Society. (2012). Design guidance for strengthening concrete structures using fibre composite materials. Technical Report No. 55. London.

[26] Weber Building Solution. (2015). http://www.netweber.co.uk/

[27] ABAQUS (2013). Theory Manual, User Manual and Example Manual, Version 6.12, Dassault Systemes Simulia Corp., Providence. 
[28] Cornelissen, H. A. W., Hordijk, D. A. and Reinhardt, H. W. (1986). Experimental determination of crack softening characteristics of normal weight and lightweight concrete. Heron, 31(2), pp. 45-56.

[29] Lu, X. Z., Teng, J. G., Ye, L. P. and Jiang, J. J. (2005). Bond-slip models for FRP sheets/plates bonded to concrete. Engineering structures, 27(6), pp.920-937.

[30] Daud, R., Cunningham, L. and Wang, Y. (2015). Numerical study of effective bond length for externally bonded CFRP plate under cyclic loading. In A. J. Gill, and R. Sevilla (Eds.), Proceedings of the 23rd UK Conference of the Association for Computational Mechanics in Engineering. Swansea: University of Swansea, pp. 359-362.

[31] Daud, R., Cunningham, L. and Wang, Y. (2015). Non-linear FE Modelling of CFRPstrengthened RC slabs under cyclic loading, Athens Journal of Technology and Engineering, 2(3), pp.161-180.

[32] Nilson, A. H., Darwin, D. and Dolan, C. W. (2010). Design of concrete structures. 14th edition in SI units. McGraw-Hill Companies.

[33] Harajli, M. H., and Soudki, K. A. (2003). Shear strengthening of interior slab-column connections using carbon fiber-reinforced polymer sheets. Journal of Composites for Construction, 7(2), pp. 145-153.

[34] Farghaly, A. S., and Ueda, T. (2010). Prediction of punching shear strength of two-way slabs strengthened externally with FRP sheets. Journal of Composites for Construction, 15(2), pp. 181-193.

[35] Jendele, L. and Cervenka, J. (2006). Finite element modelling of reinforcement with bond. Computers and Structures, 84(28), pp. 1780-1791.

[36] Faria, D. M., Einpaul, J., Ramos, A. M., Ruiz, M. F. and Muttoni, A. (2014). On the efficiency of flat slabs strengthening against punching using externally bonded fibre reinforced polymers. Construction and Building Materials, 73, pp. 366-377.

[37] Guandalini, S., Burdet, O. L., and Muttoni, A. (2009). Punching tests of slabs with low reinforcement ratios. ACI Structural Journal, 106(1), pp. 87-95. 